\title{
Donor Political Economies and the Pursuit of Aid Effectiveness
}

\author{
Simone Dietrich \\ Department of Political Science \\ University of Missouri \\ dietrich.simone@gmail.com
}

\begin{abstract}
In response to corruption and inefficient state institutions in recipient countries some foreign aid donors decrease bilateral government-to-government aid flows and increase the share of bilateral aid by outsourcing delivery to non-state development actors. Other donor governments continue to support state management of aid despite corruption and inefficiency, seeking to strengthen recipient states. These cross-donor differences can be attributed in large measure to different national orientations about the appropriate role of the state in public service delivery. Countries that place a high premium on market-efficiency (e.g. US, UK, Sweden) will outsource aid delivery in poorly governed recipient countries to improve the likelihood that aid reaches the intended beneficiaries of services. In contrast, states whose own political economies emphasize a strong state in service provision (e.g. France, Germany, Japan) continue to support state provision. This argument is borne out by a variety of tests, including statistical analysis of dyadic time-series cross-section aid allocation data and individual-level survey data on a crossnational sample of senior foreign aid officials. To understand different aid policies, one needs to understand the political economies of donors.
\end{abstract}




\section{Introduction}

Foreign aid is justified as a response to needs in poor countries, but its quantity and form depend on political and economic conditions in donor countries. For instance, research has long recognized that aid serves as an instrument of state-craft used to advance developmental and non-developmental goals, which can include policy-concessions, recipient government stability, counter-terrorism, access to natural resources, and democratization. ${ }^{1}$ Yet, donors differ significantly in bilateral aid giving. Domestic determinants of donor activity include donor country size, socioeconomic values, political party ideology, welfare institutions, budget size, domestic development NGOs, aid agencies, decision-makers' perceptions of their states' role in world politics, and elites' ideas about why aid is valuable. ${ }^{2}$

These existing studies on bilateral aid rely on the assumption that bilateral ODA activities are fungible government-to-government aid transfers. In reality, however, donors channel bilateral aid through multiple channels outside the recipient government, including international and local NGOs, international organizations like the United Nations or the Global Fund, ${ }^{3}$ and even private companies. For example, in 2007 OECD governments outsourced over 30 percent (approximately US $\$ 41$ billion) of their bilateral aid to non-state development actors -thus "bypassing" the recipient government. Previous research shows that donor governments, on average, employ bypass tactics in environments where poor governance poses a direct threat to effective aid delivery through the government-to-government channel. Out of effectiveness concerns, donor officials turn to third-party actors for more effective aid delivery channels. While donor governments such as the United States and the United Kingdom closely follow this delivery model, other donors, such as France and Germany are less likely to resort to bypass tactics under conditions of poor governance. ${ }^{4}$ This raises the central question for this paper: why are some OECD donors more likely to use government bypass tactics in countries with poor governance, while others prefer to stick with government-to-government aid?

I address this puzzle by developing and testing a model of endogenous aid delivery that accounts for heterogeneity in donor delivery preferences. I argue that donor differences in aid delivery are predicated on national orientations about the appropriate role of the state in service

\footnotetext{
${ }^{1}$ e.g. Bueno de Mesquita and Smith 2009; Kono and Montinolla 2009; Boutton and Carter 2013; Kapfer et al 2007; Wright 2009, respectively.

${ }^{2}$ e.g. Bertoli et al 2008; Lumsdaine 1993; Therien and Noel 2000; Chong and Gradstein 2008; Lundsgaarde 2012; Lancaster 2006; Milner and Tingley 2011; Breuning 1995; Van der Veen 2011, respectively.

${ }^{3}$ International organizations like the UN increasingly rely on bilateral aid as source of financing, which increases the amount of projects that they implement directly on behalf of donor governments (e.g. Knack 2013a). Bilateral funding of international organizations is distinct from multilateral aid.

${ }^{4}$ OECD Creditor Reporting System 2012.
} 
delivery. Foreign aid officials from governments with neoliberal political-economic policies turn to bypass when the public sector in the recipient country poses high risks for aid delivery. In donor countries where the organization of the political economy emphasizes a stronger state in service delivery, officials stress the importance of the public sector for the recipient country's long-term development and thus manage risks through direct involvement in the implementation of government-to-government aid. ${ }^{5}$ While statist donor elites view the role of aid as catalytic, contributing to development and growth by strengthening state capacity, their counterparts from market-oriented political economies view aid as an effort to directly improve the lives of the poor abroad, if necessary without engaging the recipient government.

This study makes three contributions to the foreign aid literature. First, it establishes that aid delivery mechanisms are a fundamental feature of foreign aid decision-making. Second, the paper presents a new framework that builds on separate foreign aid research agendas by showing how donor and recipient characteristics interact to influence donor decision-making. Third, the paper illuminates previously unexplored linkages between the organization of domestic political economies and foreign aid policy. By tracing the application of neoliberal economic policy in its application to foreign aid delivery across donor countries, I show that the domestic political economy of donors profoundly affects how they provide bilateral foreign aid. ${ }^{6}$ Thus, the results of this paper directly reinforce a prominent line of work by Katzenstein, Gourevitch, Simmons, Milner, Mansfield and Pevehouse, Nelson, and others that emphasizes the importance of domestic factors on foreign policy. ${ }^{7}$

\section{A Two-Part Theory of Bypass in Bilateral Aid}

Every year donor governments provide bilateral aid to developing countries, many of which exhibit unproductive situations in which aid goes to waste through corruption or limited capacity on the part of state institutions. ${ }^{8}$ One common approach to reducing the risk of aid capture $^{9}$ in bad governance environments is to outsource the delivery of foreign aid to non-state

\footnotetext{
${ }^{5}$ These mechanisms include conditionality, project-type foreign aid, and technical assistance.

${ }^{6}$ The importance of political economy structures has also been demonstrated in a series of studies that explain comparative political economy outcomes (e.g. Hall and Soskice 2001).

${ }^{7}$ e.g. Katzenstein 1978; Gourevitch 1986; Simmons 1994; Milner 1997; Mansfield and Pevehouse 2006; Nelson 2014; See Lake 2009 for a review of this literature.

${ }^{8}$ As analytical and empirical work on donors' aid implementation record shows, aid transfers between donor and recipient governments are at great risk of aid capture through agency problems and bureaucratic inefficiencies in poorly governed countries (e.g. Svensson 2000).

${ }^{9} \mathrm{I}$ define aid capture broadly as resulting from the mismanagement of aid in the recipient, either by intentional diversion of aid through corrupt authorities/bureaucrats or the waste of aid due to a lack of absorptive capacity. This definition differs from Svensson's (2000), Winters (Forthcoming) and Jablonski (Forthcoming) who define aid
} 
actors. These non-state actors include local and international NGOs, international organizations, and private development contractors. This tactic has been described as bypass. Recent experimental evaluations in Kenya by Bold et al (2013) and Duflo et al (2012) suggest that NGO-administered school programs perform better than government-administered programs in improving education. Thus, there is some evidence that bypass can be a more effective delivery channel.

However, bypass is hotly contested among donor countries and marked differences exist in the degree to which donor governments pursue bypass tactics abroad. While some donor governments utilize bypass tactics in bad governance environments, others make more limited use of it under similar conditions. Instead, the latter are more likely to pursue tactics that engage the government but that include mechanisms of control and oversight. Like bypass tactics, this more "hands-on" delivery tactic is designed to mitigate the rise of aid capture in recipient countries. Unlike bypass, this delivery mechanism hinges on engagement with the recipient government. These contrasting approaches raise the question of why donor governments use opposing strategies for pursuing the same goal in similar environments.

The ideas that undergird the organization of donor governments' political economies provide a potential answer to this puzzle. I argue that the debate about the appropriate strategy to deal with the risk of aid capture in poorly governed environments is largely ideological, as it reflects contrasting conceptions about the role of the state in aid delivery. Bypass tactics under conditions of bad governance emphasize efficiency gains in aid delivery through the use of market-type mechanisms. "Hands-on" government-to-government aid delivery emphasizes the importance of continued state engagement and capacity-building in aid delivery under similar conditions. It is for that reason that we expect national structures in donor countries to matter for aid delivery.

For this paper, the primary division among political economies is the mode of governance, the "kind" of state involvement in goods and service delivery rather than its size. The central question is who implements public sector policy - i.e. to whom the money gets channeled for implementation. During the first decades after World War II, Keynesian economic theory led to a broad consensus about the importance of the state in development. ${ }^{10}$ Across Western industrialized states, governments opted for a strong role of the state in delivering goods and services. In response to global economic crises in the 1970s, neoliberal ideas led to a significant change in how the state was perceived across many OECD countries. In response, many governments

capture as acts of corruption.

${ }^{10}$ e.g. Tanzi 2011 
re-organized their political economies on principles of reducing the state, deregulating markets, and privatizing government services. In goods and service provision, neoliberal beliefs demanded government change from the role of direct provider into a role that focused on channeling public resources to attain policy goals in an efficient and effective manner -by creating and relying on an open market where public and private entities compete for contracts to implement policy. ${ }^{11}$ This separation of demand from supply was famously captured by Osborne and Gaebler (1992) as "steering not rowing." Greater emphasis was put on the use of benchmarks to indicate the efficiency and/or effectiveness of a program or implementing entity. ${ }^{12}$ Knowledge of and perceptions about the relative effectiveness of public and private delivery channels increasingly determines who wins delivery contracts in goods and service provision. ${ }^{13}$ Over the last thirty years, as more governments adopted benchmarking practices in resource allocation, the rate of outsourcing of public responsibilities to non-state entities has increased. ${ }^{14}$

Today, the United Kingdom leads the outsourcing ranking where expenditure of government outsourcing to non-state actors for goods and services used by "general government" are at 14 percent of GDP, closely followed by the United States, Canada, and Australia. ${ }^{15}$ Since the early 1990s we also observe a consistent increase in the privatization of public service delivery in Scandinavian countries: severe recessions in the 1990s lead to a crisis of the welfare state, which in turn, led to significant changes in the role and institutional character of the state in the economy and public goods provision. ${ }^{16}$ Across Scandianvian economies, the introduction of private markets in welfare states, including health, child and elderly care, and education, ${ }^{17}$ led to a paradigmatic shift in national orientation from big to small state in service delivery delivery. Today, Denmark, Sweden, and Finland spend around ten percent of their GDP on government outsourcing to non-state actors for goods and services used by "general government." 18

I argue that national orientations about the role of the state in domestic goods and service provision affect foreign aid decision-making. Officials approach delivery decisions abroad in ways that are analogous to their practices at home: i.e. they rely on benchmarking practices for determining the relative effectiveness of the recipient government in implementing aid projects,

\footnotetext{
${ }^{11}$ Bertelli 2012.

${ }^{12}$ This form of public sector governance has its intellectual origins in New Public Management (NPM). The key idea in NPM is that of performance measurement, which requires the use of benchmarks to assess effectiveness.

${ }^{13}$ e.g. Hood 1995.

${ }^{14}$ Metcalfe and Richards 1990; Lundsgaard 2002. The degree to which performance-measurement has been adopted varies across OECD countries, however (Volkov and Baron 2011).

${ }^{15}$ OECD National Account Statistics Database 2011

${ }^{16}$ Andersen, Holmstrom, Honkapohja, Korkman, Soderstrom, and Vartiainen 2007.

${ }^{17}$ e.g. Gingrich 2011, Ansell 2010.

${ }^{18}$ OECD National Account Database 2013.
} 
as compared to aid delivery through other means. ${ }^{19}$ The focus of benchmarking is on risks associated with government-to-government delivery. Knowledge about the risk of aid capture through the recipient public sector then affects perceptions about the relative effectiveness of the recipient government as a delivery channel. Good governance signals a lower probability of aid capture through the state, while bad governance signals a higher probability of aid capture through corrupt and inefficient state institutions.

When quality of governance is high, officials, across political economies, have a preference for government-to-government aid. By working with the recipient state, donors can continue to exert policy influence. Good governance also serves as an indicator for the existence of indigenous development capacity and the government's commitment to development. Such environments provide important local economies of scale that can increase the returns aid. ${ }^{21}$ In poor governance environments, on the other hand, knowledge about high risks for governmentto-government aid transfers makes it less likely that neoliberal officials enter in aid delivery contracts with the recipient government. Because these countries have great demand for foreign assistance $^{22}$ neoliberal donors turn to alternative mechanisms of aid delivery, such as NGOs based in donor countries, international organizations, and private companies. ${ }^{23}$

As a former senior U.S. official highlights: "We have a high stated concern for fiduciary- and results-risks in foreign aid. These concerns translate into why a lot more of U.S. assistance is provided through NGOs or private firms. If we want our food security program to lift 15 million people out of poverty in five years in a given country, then it is hard to turn the money over to the recipient government and expect them to reach the targets, especially when the government is corrupt and lacks absorptive capacity." ${ }^{24}$ Another official elaborates further: "Governance is a big issue for us. We always care about it. When we learn of severe corruption in government we turn to our NGOs to deliver our assistance. Or, alternatively, we work with multilateral organizations like the UN Office for Drugs and Crimes [in Central Asia, added by author] by funding individual activities because they are well placed and they can deliver for us. We need to make sure that people get our help. If we continued working with the government we would

\footnotetext{
${ }^{19}$ According to more than seventy author interviews with senior officials from seven OECD donor countries ${ }^{20}$ decision-makers regularly examine a recipient country's performance in corruption, government effectiveness, bureaucratic quality, and the rule of law.

${ }^{21}$ Recent empirical and theoretical research discusses the positive effects of engaging with the local public sector in good governance environments e.g. Winters 2010; Hefeker and Michaelowa 2005.

${ }^{22}$ Radelet 2004.

${ }^{23}$ Compared to recipient governments, these non-state actors are more easily monitored and held accountable than corrupt recipient governments.

${ }^{24}$ Author's interview with former senior US government official, Paris, France, September 25, 2013.
} 
not get anywhere." 25

On the other hand, Japan, South Korea, France, and Germany place greater emphasis on maintaining the state's "rowing" function -which implies a more active role of the state in development, and more specifically in service delivery. While these economies, too, have increased competition in the public sector over the last two decades by introducing market-type mechanisms into goods and service delivery, they have done so to a lesser degree. According to the National Accounts Database these four countries spend less than 8 percent of GDP on government outsourcing. ${ }^{26}$ Public sectors have retained their capabilities to design and implement policy. In these countries, the state not only generates the demand but also assumes the role of the agent that generates supply in-house (e.g. France) - or, alternatively, coordinates the supply via institutionalized, not necessarily market-based cooperation with non-state entities (e.g. Germany). ${ }^{27}$

A senior Japanese government official explains the affinity between domestic and foreign policy decision-making, and their implications for objectives in foreign aid: "The philosophy of Japanese aid is, in part, based on our own development after the World War II where we had a very strong state leadership and state capacity. In essence, Japan's growth was led by the state. We were not a socialist country but it was civil servants who planned development and led the country and this was successful to a certain extent. And we believe that in developing countries there should be a capacity on the state-side to be able to plan ahead and manage resources and allocate them adequately and properly. We place a lot of emphasis on working with the recipient state, working with public servants to realize a collective solution to development, just like we do at home." 28

Thus, donor officials from countries where the state assumes a more involved function in service delivery are less likely to bypass recipient governments under conditions of bad governance. To mitigate risk of aid capture in poor governance environments, these donor officials prefer "hands-on" involvement in government-to-government aid transfers, ${ }^{29}$ whereby donor governments can address inefficiencies through increased technical support and donor oversight.

\footnotetext{
${ }^{25}$ Author's interview with senior US government official, State Department, Washington DC, June $09,2009$.

${ }^{26}$ OECD National Accounts Statistics Database 2011.

${ }^{27}$ This type of cooperation is the result of corporatist bargaining or historical association (see e.g. Hall and Soskice 2001).

${ }^{28}$ Interview with senior Japanese Official, Member of the Japanese Permanent Delegation to OECD, Paris, August 12,2013 .

${ }^{29}$ It is beyond the scope of this paper to fully explore the range of "hands-on" aid delivery strategies. This paper focuses on explaining variation in bypass tactics. Evidence about the effect of political economy on government-togovernment delivery tactics (e.g. technical cooperation aid) fully supports the paper's central thesis. It is available from the author upon request.
} 
Advocates of this tactic emphasize the importance of engaging with the public sector and improving local institutions for long-term development. As a French aid official suggests during the interview: "In France we respond to and penalize corrupt practices in the public sector but not by cutting aid to the government and shifting it to NGOs. We mitigate corruption through our strong due diligence process within the AFD [Agence Française de Développement, added by author]. In fact, France is at the maximum of government-to-government cooperation where we work closely with the institutions of our partners. If they have weak institutions we need to continue working with them, and accompany them with our capacity. We give them frequent advice where needed. We have almost daily dialogue with our partners on sector program choices and on the implementation of the projects. In fact we have offices of the AFD with experts in almost every country in which we work. We consider that it is not a good way to accept project implementation from an agency outside their own local structure." ${ }^{30}$ This suggests that donors can resort to different tactics to mitigate the risk of aid capture in recipient countries. Consistent with this paper's argument, the choice of delivery mechanism depends on donor countries' political economies.

A potential rejoinder to this argument linking donor political economies and foreign aid delivery is the possibility that foreign policy is a policy arena completely distinct from domestic policy. Indeed a rich literature on the "Two Presidencies" in American Politics seeks to determine whether presidents exercise more power over foreign policy than domestic policy. While the evidence remains mixed, several studies suggest that presidential influence is greater in foreign policy. ${ }^{31} \mathrm{My}$ argument, on the other hand, asserts that domestic economic policy-making encroaches on foreign economic policy via shared beliefs about the role of the state. ${ }^{32}$ These beliefs not only influence the organization of donor political economies but they ensure their persistence by shaping rules and regulations across policy areas. ${ }^{33}$

I identify cross-cutting legislative frameworks as a primary mechanism through which national orientations about the appropriate role of the state influence domestic and foreign policy making. To illustrate, I draw on U.S. legislation that anchors the "three M's" 34 -markets, managers, and measurement- in public sector governance. The U.S. Performance and Results Act (GPRA) from 1993 drafted under G H Bush, signed by Clinton ${ }^{35}$-and revised by Obama in

\footnotetext{
${ }^{30}$ Interview with senior French government official, Permanent Delegation to the OECD/DAC, Paris, July 3, 2013.

${ }^{31}$ Wildavsky 1966, Sullivan 1991, Peterson 1994.

${ }^{32}$ Milner and Tingley 2014 argue that domestic politics influences foreign policy via domestic interest group pressures.

${ }^{33}$ See Goldstein and Keohane 1993 for applications about the influence of ideas on foreign policy.

${ }^{34}$ Ferlie, Fitzgerald, Pettigrew 1996

${ }^{35}$ www.whitehouse.gov/omb/mgmt-gpra/gplaw $2 \mathrm{~m}$
} 
$2010,{ }^{3637}$ tied performance results to budgetary decisions. It required all federal agencies to produce -a strategic plan with organizational goals and objectives; -a performance plan including measurement and data on meeting objectives; and -a performance report including actual performance data. The legislation increased pressure across all agencies to carefully benchmark and manage for effectiveness by relying on markets. GPRA not only resulted in increased performance-based evaluation. It also caused a shift in resources away from programming and in-house policy implementation, which resulted in capacity loss in these functions. GPRA had direct effects on foreign aid agencies including USAID. It required USAID to adopt greater performance-based measurement of foreign aid program, and simultaneously contract out USAID technical and program design functions to private actors in order to compensate for loss in operational capacity. ${ }^{38}$ Domestic government agencies, like the U.S. Office of Management and Budget, ensure that these legislative reform initiatives are properly enforced. In Sweden agencies like the Agency for Public Management and the National Financial Management Authority play important roles in enforcing public management reforms in foreign aid. ${ }^{3940}$

Insofar as donors seek to promote economic development I argue that decision-making in foreign aid delivery is shaped by the interaction of a donor's national orientation about the role of the state in public service delivery and governance characteristics in the recipient country. ${ }^{41}$ Based on this logic, I advance the study's main hypothesis: Donor officials from political economies that emphasize the market in goods and service delivery should be more likely to bypass the public sector in recipient countries with poor governance quality than their counterparts from political economies that emphasize a stronger role of the state in goods provision.

\section{Research Design, Data and Measures}

I explain variation in donor outsourcing tactics across 23 OECD donor countries. The universe of recipient countries includes ODA eligible countries as defined by the OECD. I use cross-national observational and elite survey data to test the argument. First I test my claim at the level

\footnotetext{
${ }^{36}$ www.whitehouse.gov/omb/performance/gprm-act

${ }^{37}$ GPRA has its intellectual roots in NPM.

${ }^{38}$ Natsios 2010.

${ }^{39}$ Christensen and Laegreid 2013.

${ }^{40}$ For instance, in 2011, the Swedish Agency for Public Management published a critical of Swedish aid policyconcluding that the existence of too many uncoordinated policy documents weakened the scope for government management for results. The report triggered immediate changes in aid policy consistent with recommendations (Oden 2013).

${ }^{41}$ This argument does not maintain that donors use aid only to maximize development. The scope condition for my argument is that in the cases to which it applies, economic development is one of their major objectives.
} 
of the donor-recipient dyad-year -where temporal domain ranges from 2005 to 2011 because of data availability. Second, I present originally collected survey data on a cross-country sample of senior aid officials from donor countries where public sectors rely on markets for the delivery of services (United States and Sweden) and their counterparts from countries where the state assumes a more active role in service delivery (Japan, France, and Germany).

\section{Cross-Country Analysis of Aid Delivery}

\section{The dependent variable: outsourcing in bilateral aid}

The outcome of interest is donor decisions to outsource the delivery of foreign aid to non-state actors. I construct this measure using data drawn from the OECD CRS aid activity database. ${ }^{42}$ Information on the channel of delivery records the amount of bilateral aid flows channeled through different channel categories. I distinguish between government-to-government aid and aid channeled through non-state development actors. I define government-to-government aid as any aid activity that involves the recipient government as an implementing partner. In contrast, aid delivered through non-state development channels does not engage government authorities, and goes to non-state actors for purpose of project implementation. The primary non-state actors in this category include international and local NGOs, international organizations, public private partnerships, and private companies. There is also a small residual channel category that includes research institutes and networks as non-state implementation partners.

I operationalize the decision to outsource with a continuous measure, capturing the proportion of aid delivered through non-state development actors. Figure 1 presents the proportion of non-state aid each donor country allocates (y-axis) across the full volume of aid flows in 2009. Among OECD donors, Finland channels the greatest proportion of aid through bypass actors, nearly 70 percent, followed by Canada, Norway, and Ireland. The United States outsources more than 30 percent of its bilateral funds. At the low end of the bypass axis are France, Greece, and Korea, which send less than eight percent of their aid through bypass channels.

[Figure 1 here]

\footnotetext{
${ }^{42}$ The OECD began collecting information on the "channel of delivery" in 2004.
} 


\section{The explanatory variables: donor political economy and quality of re- cipient governance}

Measuring national delivery preferences for goods and services: My argument builds on differences in national orientations about the role of the state in goods and service delivery. I conceptualize the main division among donor countries to be based on different mechanisms through which governments deliver goods and services. In some countries neoliberal beliefs promote competitive markets in delivery systems. In other countries more statist beliefs advocate non-market relations in goods and service delivery, either via in-house delivery or institutionalized delivery agreements with non-state actors. To capture this variation in ideas that undergird the organization of political economies I rely on pre-existing theoretical frameworks in the study of comparative political economy.

In a first step I leverage the binary division developed in the Varieties of Capitalism tradition, which distinguishes political economies by types of governance modes. ${ }^{43}$ In liberal market economies (LMEs) governments organize economic activity largely through markets -and economic decision-making is a function of market-based competition. Consistent with VoC coding, I group the following Anglo-American donor countries in the neoliberal market category: United States, United Kingdom, Ireland, Australia, New Zealand, and Canada. To account for recent paradigmatic changes in national orientations from non-market to market-based delivery systems across Scandinavian countries ${ }^{44}$ I include Scandinavian countries in the LME category. ${ }^{45}$ In coordinated market-economies (CMEs), on the other hand, governments frequently organize economic activity through non-market-based relationships that emerge from corporatist bargaining and/or include various forms of state intervention and regulation. I group France, Japan, South Korea, Germany, Austria, Netherlands, Switzerland, and Belgium in the CME category. I create an "other" category which subsumes countries with hybrid political economy types that include Spain, Portugal, and Greece. ${ }^{46}$ I use the "other" category as baseline category against which I statistically evaluate aid delivery patterns of LMEs and CMEs. Italy is excluded due to missingness of aid delivery data.

In a second step I further differentiate the binary division to account for differences in state

\footnotetext{
${ }^{43}$ e.g. Estevez-Abe, Iversen, and Soskice 2001; Franzese 2002; Hall and Gingrich 2009.

${ }^{44}$ Steinmo 2010; Cohen et al 2011; Gingrich 2011 offer compelling accounts of this change.

${ }^{45}$ The results do not change if I exclude Sweden, Norway, Denmark, and Finland from the the LME sample in the analyses.

${ }^{46}$ The Varieties literature has labeled them "Mediterranean Market Economies (e.g. Hall and Soskice 2001). Quinn and Inclan 1997 label these countries "syndicalist" (Quinn and Inclan 1997). In addition, Greece, Spain, and Portugal differ from the other OECD donors insofar as they were recently recipients of EU assistance themselves.
} 
structures among CME states. Katzenstein's and Evan's work shows that different kinds of state structures create distinct action capacities, and thus define the range of roles the state plays. ${ }^{47}$ For instance, the professional bureaucracies in France historically produce and implement goods and services in-house. ${ }^{48}$ We find similar patterns in Japan and South Korea. Germany also relies on in-house delivery capacity but, simultaneously, delegates goods and service delivery to nonstate actors with whom the government has an institutionalized relationship. The latter type of delivery through non-state actors is not a function of market-competition. Rather it arises from corporatist bargaining. Katzenstein labels this political economy type neocorporatist. ${ }^{49}$ I follow suit and include Germany, Austria, Belgium, Switzerland, and the Netherlands in this category. Traditionally, Scandinavian economies have been described as neocorporatist where the state delivers goods and services through institutionalized arrangements with nonstate actors. However, economic crises in the 1990s brought about a fundamental change in delivery mechanism toward markets. I thus add a fourth political economy type that I label "Scandinavian." Again I include Spain, Portugal, and Greece in the "other" category and use them as reference category in the statistical tests.

In a third step, I draw on a proximate expression of how political economic order occurs in politics in donor countries -a measure of "domestic government outsourcing" of services used by the general government as percent of GDP. I expect this measure to be determined by ideas that undergird the organization of political economies, which are captured by the previous political economy types. These data are from the OECD National Accounts Database and measure the degree to which governments use private contractors or the third sector to provide support services or perform back-office functions. ${ }^{50}$ These data are only available for 2000 and 2009. In 2009, domestic government outsourcing of goods and services used by general government as percent of GDP represented an average of twelve percent across the OECD donor governments. In Figure 2 I plot the level of Government Outsourcing across all donor governments in 2009. This measure varies considerably from 3.5 percent in Japan to twelve percent in the United Kingdom. ${ }^{51}$ The outsourcing average in 2009 is only a two-percent increase from the average outsourcing in 2000, which implies that outsourcing does not change much over time. In subsequent analyses, I therefore employ a country's outsourcing average

\footnotetext{
${ }^{47}$ Katzenstein 1976, 1985; Evans 1995.

${ }^{48}$ e.g. Suleiman 1974

${ }^{49}$ e.g. Katzenstein 1985.

${ }^{50}$ OECD National Accounts Database 2011.

${ }^{51}$ For robustness, I construct an alternative proximate expression measure, government outsourcing of goods and services used by general government as percent of government spending, and plot the distribution in Figure A1 in the Appendix. The subsequent results do not change if I include the alternative outsourcing measure.
} 
between 2000 and 2009 .

[Figure 2 here]

Indeed, Figure 3 demonstrates that domestic government outsourcing is highly correlated with political economy types: while the Scandinavian type slightly tops the neoliberal one in domestic government outsourcing, the difference between these two (9.1 and 9.8 percent) and statist and neocorporatist types (4.5 and 4.9 percent) is considerable.

[Figure 3 here]

Measuring quality of recipient governance: When determining aid delivery tactics, aid decision-makers assess the likelihood of aid reaching the intended outcome in the recipient country. If state institutions are of poor quality, donor officials expect a higher probability of aid capture. In advancing the argument that national orientations condition the selection of delivery tactics when facing risk, I presume that, among officials from neoliberal economies there is a greater propensity to rely on bypass than among officials from more statist political economies. The quality of recipient governance is, therefore, an important variable in the model. I draw on data from the Governance Matters project. ${ }^{52}$ I construct the Recipient Governance variable by including corruption control, government effectiveness, regulatory quality, and rule of law as indicators and averaging across them for any given year. The governance variable ranges between -2.5 and +2.5 , which I rescaled to 0 and 5 , with higher values representing a higher quality of governance. Among aid-receiving countries there is no country with a governance rating of 4 and higher. ${ }^{53}$ Subsequent graphical illustrations will provide a 0 - 4 range of the variable.

In some aid-receiving countries, however, most notably in failed states, donors might face functionally incompetent governments, thus rendering bypass the sole aid delivery channel. To address this issue of constraint, I present the subsequent descriptive data using four different development environments in recipient countries that account for functional competence. ${ }^{54}$

\footnotetext{
${ }^{52}$ Kaufman, Kraay, and Mastruzzi 2011. The project offers data for six governance dimensions: voice and accountability, regulatory quality, government effectiveness, rule of law, corruption control, and political stability and violence. I select this particular source of governance measures because author interviews with donor officials suggest that donor government and aid agency representatives consult this publicly available governance source in their assessments. In over half of the author's interviews with donor officials, respondents specifically mentioned World Bank governance data as informing their assessments.

${ }^{53}$ See a histogram of Recipient Governance in Figure A2 in the Appendix.

${ }^{54}$ In robustness tests below, I exclude the top 10 fragile states, using data from the "Foreign Policy Failed States Index to determine "fragility." The results are the same.
} 
To illustrate recent donor aid delivery decisions in various situations of governance quality, I plot donor development cooperation for aid-receiving countries in 2009, where individual donors contributed at least 2 million US dollars in development assistance. Figure 4 shows the bypass behavior of all active OECD donors in four recipient countries that vary in their governance characteristics. The countries include Sudan (a poorly governed, "failed" state), Sri Lanka (still poorly governed, functionally competent state), Tanzania (a better-governed, functionally competent state), and Cape Verde (a well-governed, functionally competent state) across the full range of possible bypass behavior (as captured along the x-axis).

[Figure 4 here]

In the Sudan, which has a governance score of 0.86, all donor governments, with the exception of Greece, bypass the Sudanese government with more than 50 percent of their bilateral assistance. In the case of Sri Lanka, which has a governance score of 1.90, a majority of donors bypass with more than 50 percent of their bilateral assistance, and some donors outsourcing a somewhat lower proportion. Tanzania, scores a 2.3 on the scale, and, as expected, the majority of donors, with the exception of Norway, Finland, and Switzerland, channel less than half of their aid through non-state channels. In Cape Verde, which scores 2.98 on the governance scale, donors channel only a small proportion through non-state actors.

While this graph provides descriptive evidence that donors, on average, respond to the quality of recipient institutions, differences nonetheless remain across donors. For instance, Japan and France do not outsource foreign aid in Sudan and Sri Lanka to the same extent as the United States, the United Kingdom and Sweden. Moving from Sri Lanka to Tanzania the latter three countries exhibit a different delivery tactic in favor of working with the recipient government, now more similar to Japan and France.

Figure 5 presents descriptive statistics that provide prima facie evidence that differences in aid delivery tactics exist across political economy types. The y-axes represent the mean share of bypass. This mean share is separated into aid recipients that have "Bad Governance," depicting countries with governance score of 1.5 and lower, and aid recipients that have "Good Governance," or a governance score of 2.0 and higher. The whisker plots are useful for illustrating the change in outsourcing share across the two types of political economies when moving from environments of high probability of aid capture to low probability ones. The raw data indicate that, regardless of political economy type, donors are responsive to the probability of aid capture in the recipient country. Importantly, however, we observe that the degree to which countries 
bypass recipient governments varies by political economy type. The left graph depicts differences between the CME and LME countries, whereby the LME countries exhibit greater reliance on markets than their CME counterpart, which is indicated by the relatively steep drop in bypass shares as the quality of governance changes from bad to poor. In the right graph we find that neoliberal and Scandinavian political economies exhibit the steepest relationship when moving from poorly to better-governed recipient countries in the left panel.

[Figure 5 here]

\section{Controls}

As the previous literature on aid policy maintains, various other factors shape donor decisions about the allocation of aid resources, including other recipient characteristics and nondevelopmental donor goals. I include them as controls to provide a fully specified model. All time-varying right-hand side variables are lagged one year. I control for Democracy based on the understanding that some donors may conceive of democratic institutions as political constraints that limit the ability of recipient governments and bureaucratic officials to capture aid flows. Democracy is measured using the combined score of the Freedom House civil liberty and political rights indicators. ${ }^{55}$ To make the scale of the measure more intuitive I invert Democracy so that "1" represents the lowest level of democracy, while " 7 " stands for the highest level of democracy. ${ }^{56}$ I control for Natural Disaster Deaths based on the understanding that a greater number of deaths caused by natural disasters in the aid recipient, as recorded by EM-DAT, may prompt donors to provide a larger share of the pie to non-state development actors that are specialized in post disaster reconstruction efforts. ${ }^{57}$ Following a similar logic, low-scale Civil Conflict, as recorded by Gleditsch et al's PRIO database, may create grievances that provide incentives for donors to favor more outcome-orientated aid delivery about ensuring that aid reaches the affected, thus increasing donor propensity to bypass. ${ }^{58} \mathrm{I}$ further include Distance to account for the geographical proximity between donor and the aid-receiving countries. As distance between donors and aid-receiving countries grows, government-to-government relations between donor and recipient governments are expected to weaken, thus increasing donor propensity to channel aid through non-state development actors. The distance data are drawn from Bennett

\footnotetext{
${ }^{55}$ Freedom House 2012.

${ }^{56}$ The Freedom House data are widely used among donor governments in their assessments of democracy. In robustness tests I use polity2 as measure for the democracy. The results are very similar.

${ }^{57}$ EM-DAT 2013

${ }^{58}$ Gleditsch, Wallensteen, Eriksson, Sollenberg, and Strand 2012.
} 
and Stam's Eugene software and are logged ${ }^{59}$ Following previous studies, I also include confounders that capture donor non-developmental objectives. Former Colony status, as recorded by the CIA World Factbook, allows me to account for long-lasting diplomatic ties between the donor and the aid receiving governments that may bias aid delivery in favor of government-togovernment aid. Trade Intensity, measured as the logged sum of imports and exports between the recipient and the OECD countries from the IMF-DOT database, is a straightforward indicator of donor efforts to strengthen economic ties with the recipient government. ${ }^{60}$ To control for security related donor goals, I include Security Council, which is a binary variable indicating whether the aid recipient is a rotating member on the UN Security Council. As research by Kuziemko and Werker finds, donor governments use aid to buy votes from rotating members of the UN Security Council. ${ }^{61}$

I incorporate a binary control for Major Power status to account for the fact that major donors including the US, UK, Japan, Germany, and France use foreign aid to influence policy abroad. I also include controls for Total Aid Per Capita, as well as Democracy Aid and Social Sector Aid individually. I would expect democracy aid to have a positive effect on bypass insofar as democracy aid maybe more likely to be associated with civil society support. By including Social Sector Aid, I control for the possibility that donors channel aid through nonstate development actors because NGOs and IOs are in a better position to deliver services. This is distinct from my argument which suggests that donors turn to non-state development actors because they want to decrease the probability of aid capture.

\section{Analysis and Results}

I now estimate the model that examines differences in aid delivery across political economies using the political economy type measure. I fit a linear OLS model with a log-transformed dependent variable to account for the proportional nature of the bypass share data ${ }^{62}$ and calculate clustered standard errors on the recipient country. ${ }^{63}$ I investigate bias from serial correlation by applying the Wooldrige test for panel data. ${ }^{64}$ The significance of the test-statistic $(\mathrm{p}=$ 0.029) indicates that autocorrelation may introduce bias in the estimates. I therefore include a lagged dependent variable in the main specification. The following equation delineates the fully

\footnotetext{
${ }^{59}$ Bennett and Stam 2000.

${ }^{60}$ International Monetary Fund, Database of Trade 2011.

${ }^{61}$ Kuziemko and Werker 2006.

${ }^{62}$ I provide a brief discussion of the statistical implications of using a proportional outcome measure, i.e. compositional data analysis, in the Appendix.

${ }^{63}$ The results are robust to alternative dyadic and donor cluster-specifications.

${ }^{64}$ Wooldridge 2002, p. 282-283.
} 
specified statistical model, using the binary (LME, CME) division. ${ }^{65}$

$$
\begin{aligned}
\text { Bypass }_{i t}= & \beta_{0}+\beta_{1} \text { LaggedBypass }_{i t}+\beta_{2} \text { RecipientGovernance }_{i t}+ \\
& \beta_{3} P E_{L M E, i}+\beta_{4} P E_{L M E, i} * \text { RecipientGovernance }_{i t}+ \\
& \beta_{5} P E_{C M E, i}+\beta_{6} P E_{C M E, i} * \text { RecipientGovernance }_{i t}+ \\
& \beta_{7} Z+\epsilon_{i t},
\end{aligned}
$$

where BypassinForeignAid is the continuous log-transformed (OLS) variable, $i$ represents country and $t$ represents year, LaggedBypass captures the share of bypass in the previous year, RecipientGovernance denotes the (time-varying) quality of recipient governance, $P E_{L M E}$, $P E_{C M E}$ denote the (time-invariant) political economy types of the binary typology, and RecipientGovernance* $P E_{L M E, C M E s}$ denote the respective interactions, $Z$ denotes the vector of (time-varying and time-invariant) control variables, and $\epsilon_{i t}$ is the error term of the equation. To account for unobserved confounders across recipient countries and years in the sample I include 2-way year and recipient fixed effects in the main model specifications, as specified at the bottom of Table $1 .{ }^{66}$

[Table 1 here]

In Table 1, I present my findings. The first two columns present OLS results for the specification (Models 1 and 2) that do not include political economy variables. They include the Recipient Governance measure and other potentially confounding factors as well as donor country and region fixed effects. This specification allows me to show the average effect of Recipient Governance prior to introducing the donor invariant political economy measures. Model 2 includes the lagged dependent variable. The results show that donors, on average, condition aid delivery tactics on the quality of recipient governance. The coefficient of Recipient Governance is negative and statistically significant indicating that donors respond to improvements in governance by reducing the share of aid channeled through non-state development actors.

\footnotetext{
${ }^{65}$ The same equation is expanded to include the four-fold measure of political economy types.

${ }^{66}$ For robustness I re-estimate the main models below, Table 1 Model 4, 6, and 8, with 3-way fixed effects that include donor, recipient, and year fixed effects. The time-invariant political economy constituent terms are absorbed by the donor fixed effects, but the interaction terms are time-varying and can be interpreted (see Green, Kim, and Yoon 2001). Table A2 in the Appendix presents the results for the interaction terms for both the binary and four-fold political economy typologies, as well as the domestic outsourcing variable. As predicted the coefficient of $L M E s{ }^{*} R e c$ Gov is negative and statistically significant in Model 1. In Model 2, the Scandinavian*Rec coefficient is negative and statistically significant. The Neoliberal ${ }^{*}$ Rec Gov coefficient behaves in the predicted direction but just misses statistical significance. The Domestic Outsourcing*Rec Gov coefficient is negative and statistically significant. The subsequent Figures A3 and A4 in the Appendix plot the effects of the interaction coefficients across different values of recipient governance.
} 
The results in Models 3 to 6 provide support for my main argument, which leads me to expect that donor countries whose political economies are organized by market-principles are statistically different from other political economy types in how they respond to variation in governance quality in the recipient country. ${ }^{67}$

Models 3 and 4 present results using the binary division between LME and CME types. I focus on Model 4 since it corrects for serial correlation by including the lagged dependent variable. ${ }^{68}$ The coefficient of Recipient Governance expresses the statistical association between governance and bypass for the omitted group of donors (Spain, Portugal, and Greece), which is negative, as expected. The interaction term $L M E s^{*} R e c$ Gov is negative, which indicates a steeper negative slope for the LMEs compared to the slope of the omitted group. The LMEs constituent term is positive and significant, suggesting that moving from the omitted type to the LME category yields a significant increase in bypass when governance quality in the recipient country is 0 . The interaction term $C M E s^{*} \operatorname{Rec}$ Gov is positive, which indicates a lower degree of responsiveness to changes in governance quality, relative to the omitted group of donors. The CMEs constituent term is positive but insignificant.

Significance tests of the respective interactions $(\mathrm{p}=0.001)$ and political economy constituent terms $(\mathrm{p}=0.001)$ reveal that the two political economy types differ significantly from each other in terms of their aid delivery tactics. These findings offer statistical confirmation of initial inspections of the raw data as presented in Figure 2. Bad governance, as is the case in Sudan and Sri Lanka, has regulatory influence in terms of bypass tactics for the United States and the United Kingdom, but not France and Japan. When governance quality is higher, as is the case in Tanzania, donors who rely on markets in goods delivery are more willing to engage with the state, as it now represents a trustworthy and capable development partner -whose indigenous economies of scale are likely to boost the effect of aid delivered through the recipient government channel.

Models 5 and 6 present results for regressions that include the four-fold political economy typology. The neoliberal and Scandinavian political economies have positive and significant constituent terms, suggesting that moving from the omitted type to the neoliberal or Scandinavian category yields a significant increase in bypass when governance quality in the recipient country is 0 . Both political economy types have negative interaction terms, which indicate steeper negative slopes, relative to those of the "other" group.

\footnotetext{
${ }^{67}$ Table A1 in the Appendix presents descriptive statistics for Model 4 in Table 1.

${ }^{68}$ The size of the sample decreases from $\mathrm{N}=10605$ in Model 3 to $\mathrm{N}=8760$ in Model 4 because of the inclusion of the lagged dependent variable.
} 
Significance tests of the political economy constituent terms $(p=0.001)$ reveal that the two political economy types differ significantly from the other statist and neocorporatist political economies in terms of their aid delivery tactics. Significance tests of the interaction terms reveal that bypass tactic of neoliberal and Scandinavian political economies under condition of bad governance is jointly significantly different $(\mathrm{p}=0.002)$ from the statist and neocorporatist political economies. This suggests that they exhibit similar degrees of responsiveness to changes in recipient governance. Significance tests of the political economy constituent terms show that, again, neoliberal and Scandinavian aid delivery tactics are jointly statistically significantly different from the other two categories $(\mathrm{p} .=0.001)$ but not statistically different $(\mathrm{p}=0.66)$ from one another. ${ }^{69}$

In Models 7 and $8 \mathrm{I}$ investigate the effect of domestic government outsourcing- proximate expression of political economy type. I expect that the interaction of donor outsourcing and recipient governance contributes to explaining variation in delivery tactics. Consistent with Models 3 through 6 I focus on the interaction of Government Outsourcing and the quality of recipient governance, again controlling for potential confounders. Government Outsourcing is a continuous and time-invariant variable, measuring average government outsourcing between 2000 and 2009. The results in Model 7 and 8 provide statistical confirmation as they indicate differences in responsiveness to changes in government outsourcing. The coefficients of the interaction term and the Government Outsourcing constituent term are negative and positive, respectively. ${ }^{70}$

Figure 6 plots the marginal effects of political economy type on the share of bypass across different values of governance quality. The left panel of Figure 6 shows the results of Table 1, Model 4, which includes the binary division of political economy types. As indicated from the coefficients, the slope of the $L M E s$ is consistently negative. Differences in statistical significance are captured through $95 \%$ confidence intervals, which I visualize through stars. The stars indicate that the effects of either political economy type are statistically significantly different from the omitted "other" category (Spain, Portugal, and Greece), but not from each other. Moving into the LME category (from the baseline "Other" political economy type) yields a

\footnotetext{
${ }^{69}$ One may be concerned that the results of Models 5 and 6 are sensitive to how I group countries into the political economy types. I address this potential criticism by using the jackknife re-sampling technique. The basic idea behind the jackknife variance estimator in this application is that it systematically recomputes the statistic dropping individual donor countries from the political economy type one at a time from the sample wet. From this new set of replicates of the statistic, an estimate for the bias and an estimate for the variance of the statistic can be calculated. The changes are slight and negligible and increase my confidence in the specification of Models 5 and 6 .

${ }^{70}$ In Table A3 in the Appendix, I examine the robustness of these results using an alternative outsourcing measure, where I divide the amount of government outsourcing by government spending. The results do not change.
} 
statistically significant increase in bypass share by 0.48 in badly governed countries (with a "1" for governance quality) from the baseline "Other" type. In better governed countries (with a "3" for governance quality) the statistically significant increase associated with becoming a Scandinavian political economy type is smaller at 0.4 relative to the baseline "other" political economy type.

The right panel of Figure 6 shows the results of Table 1, Model 6, which includes the four-fold division of political economy types. As indicated from the coefficients, the slopes of the Neoliberal and Scandinavian political economies are similar and consistently negative. There are differences in statistical significance that are visualized through $95 \%$ confidence intervals captured through stars. Becoming Scandinavian (from the baseline "Other" political economy type) yields a statistically significant increase in bypass share by 0.48 in badly governed countries (with a "1" for governance quality) from the baseline "Other" type. In better governed countries (with a "2" for governance quality) the statistically significant increase associated with becoming a Scandinavian political economy type is nearly identical relative to the baseline "other" political economy type. This responsiveness to improvements in recipient governance is very similar for the classic neoliberal countries, although the differences are not statistically different from the omitted category. The slope of the Statist political economies is positive. As the quality of governance improves, this group of countries, compared to the omitted category, does not increase the share of government-to-government aid. The slope of the Neocorporatist political economy type is positive, suggesting that, compared to the omitted category, Neocorporatist countries condition less on governance as the quality of governance increases.

[Figure 6 here]

Figure 7 presents the marginal effects of government outsourcing on the share of bypass across different values of recipient governance. My argument leads me to expect that increases in domestic government outsourcing make donor governments more selective in their selection of aid delivery channels. The x-axis captures different levels of governance quality, ranging between 0 and 5 . Increasing the level of domestic outsourcing yields a statistically significant decrease in bypass share as the quality of governance increases; and this statistical relationship holds for the large majority of the data points. In other words, donor political economies that emphasize efficiency in aid delivery will cut governments slack as they improve their governance and increase the share of government-to-government aid. The evidence presented in Table 1 supports my thesis that recipient governance plays a significant role in donor decisions about how 
to deliver aid; but that differences exist across donors to the degree in which donor governments subscribe to bypass delivery tactics.

[Figure 7 here]

Among the controls Trade Intensity, Total Aid Per Capita, Former Colony, and Major Power are statistically significant across most models, and the direction of the coefficient behaves in the predicted direction. While the coefficient of Democracy behaves in the predicted direction, it is not statistically significantly associated with bypass. This may suggest that donors, on average, are not as responsive to the quality of government as they are to the quality of governance, all else equal. This finding, though resulting from a mere control variable, merits further study. The findings associated with Democracy Aid are inconsistent in terms of coefficient direction but mostly insignificant. This may be due in part because the measure subsumes both governance aid and civil society aid -which is channeled through government and civil society, respectively. Further disaggregation may be of interest for future studies. The results for Civil Conflict are insignificant, the positive direction of the coefficient was anticipated and suggests that donors increase the amount of bypass during years of conflict. This, too, merits further study and has implications for important research that investigates aid allocation during or after episodes of conflict. ${ }^{7172}$

Finally, readers might be concerned about potential endogeneity. If bypass undermines or strengthens state institutions then the quality of governance is endogenous. However, the theory does not offer clear predictions as to what direction the bias works. In author interviews, more statist donor government officials have suggested that bypass hurts recipient state institutions because it diverts resources away from the public sector and towards parallel structures that often lack alignment with public sector policy. Neoliberal government officials, on the other hand, believe that bypass creates incentives for recipient governments to improve their governance quality, as non-state actors compete with the recipient public sector for foreign aid. To address the concern statistically, I estimate a model that controls for Initial Governance, which measures the value of governance during the first year of the estimation sample. By measuring governance at the earliest possible time, I minimizing the effect of bypass on governance. What

\footnotetext{
${ }^{71}$ e.g. Flores and Nooruddin 2009; Flores and Nooruddin 2012.

${ }^{72}$ In the Appendix, Table A4, I examine the robustness of these results with additional control variables, including both the logged Number of IGOs and Number of INGOs or the Number of NGOs and IGOs in the recipient to account for potential confounding caused by the presence of international non-state actors, which may increase bypass share simply by providing more opportunity to bypass. The data are from the Yearbook of International Organizations. The results do not change.
} 
is more, recipient governance is a measure that changes slowly over time. Accounting for initial governance, the results do not change. ${ }^{73}$

\section{With-in Subject Survey Data Analysis}

I further test my argument with cross-country individual-level survey data of 55 senior aid officials from five countries. ${ }^{74}$ The countries include France, Japan, Germany, the United States, and Sweden. ${ }^{75}$. I selected these countries because of their political economy types. Four of the five donors are considered major donors. Sweden is a political economy that has undergone a change in political economy type. By supplementing cross-country analyses with survey data of foreign aid officials I am able to test important individual-level implications of my argument. I administered the survey in face-to-face interviews, either in person or on the phone. ${ }^{76}$

\section{Survey Design and Implementation}

My argument posits that aid decision-makers react to changes in the quality of governance in the recipient country and that aid officials from different political economies differ in the degree to which they use bypass tactics under conditions of bad governance in the aid-receiving country. The survey employs a within-subject design which exposed each official to three hypothetical low-income country scenarios, which differ only in the quality of governance. The anchoring scenario, Country A, represents a well-performing low income country with relatively low levels of corruption and strong state institutions. ${ }^{77}$ Countries B and C are identical to Country A, with the exception of their governance characteristics. Country B captures weak state institutions -while corruption levels are relatively low. Country C captures a large-scale corruption scandal involving public sector officials -while state institutions are relatively strong. ${ }^{78}$ Subsequent to presenting each country scenario I asked respondents to answer questions about their aid delivery preferences in their capacity as aid officials. The first question asked respondents to rankorder five aid delivery channels including the recipient government, international organizations, international NGOs, local NGOs, and private sector actors. The scale ranges from 5-"works best

\footnotetext{
${ }^{73}$ Table A5 and Figure A5 in the Appendix present the results of the main model in Table 1, Model 4, when controlling for Initial Governance.

${ }^{74}$ The current survey response rate is 85 percent.

${ }^{75}$ Table A5 in the Appendix lists the number of respondents for countries, ministries, and/or agencies.

${ }^{76}$ Nine respondents requested to take the survey online.

${ }^{77}$ Country A served the purpose of anchoring the respondents -and was thus not randomized. The large majority of respondents verbally identified Country A as a "Good Performer", which served as an implicit manipulation check.

${ }^{78}$ Country scenarios $\mathrm{B}$ and $\mathrm{C}$ were presented in random order.
} 
for my country" to 1- "works worst for my country." I focus on the rank-order associated with aid delivered through the recipient government. If respondents rank the recipient government as as "5" it means that they have a clear No Bypass preference. With descending rank order values, respondents indicate greater preferences for bypass.

To closely mimic the dependent variable of the observational data analysis I further asked respondents to indicate their preferences regarding the proportion of government-to-government aid across the three scenarios. The second question asked respondents to determine the amount of government-to-government aid out of overall aid flows to the country -with answer categories including "none," "some," "quite a bit," "a large amount," and "all." Similar to the rankorder measure, the value " 5 " is associated with a clear No Bypass preference, with lower values indicating increasing preference for bypass.

Figure 8 shows the point estimates as well as the associated confidence intervals for changes in quality of governance across aid officials from different political economies. The left panel of the Figure provides estimates for the channel rank-order measure. The right panel presents estimates for the aid delivery share outcome measure. The descriptive data confirm my expectations. Officials from both types of political economies have a preference for the governmentto-government channel when the quality of recipient governance is high. In countries with weak governance or corruption differences among officials from different political economies are pronounced. While the ranking mean is lower across both types of political economies, the mean of US and Swedish officials is statistically significantly lower. The pattern is the same for the aid delivery share measure presented in the right panel of Figure 8.

[Figure 8 here]

Next, I estimate difference in differences to measure the effect of deteriorating governance within subjects. My argument predicts that the change in delivery tactics induced by Country B and Country C scenarios differs significantly across officials from different political economies. I expect officials from the United States and Sweden, on average, to change towards greater bypass than their counterparts from France, Japan, and Germany. The results confirm my thesis and are consistent with the observational data analysis. Table 2 shows the difference in differences estimates. The upper half of Table 2 represents the results of the estimates explaining the rank-order measure, No Bypass -Ranking. The estimated difference between officials from the two types of political economies as they move from Country A to Country $\mathrm{B}$ is -1.51 and statistically significant at the 0.01 level. Moving from Country A to Country 
B yields an statistically significant estimated difference of -1.24 at the 0.01 level. The results No Bypass -Proportion are presented in the lower half of Table 2. Again, the difference in response as respondents move from Country A to Country B or C are statistically different across officials from the the two types of political economies. This suggests that officials of any background prefer to lower the government-to-government portion of bilateral aid in poorly governed countries but U.S. and Swedish respondents did so to a higher degree, with statistically significant differences in means in the case of a corruption scandal or weak state institutions in recipient countries, respectively.

[Table 2 here]

Why do we see this differential response in delivery tactics across officials? My argument posits that the organization of public goods delivery at home influences how officials approach the delivery of foreign aid abroad. Donor officials from countries that rely on markets to maximize outcomes prefer delivery tactics that achieve outcomes that are readily measurable and achievable in the short-run. On the other hand, officials from countries where public sector governance emphasizes a strong state in the delivery of public goods focus on collective long-term solutions that center on state-building efforts and, consequently, focus less on short-run results. The survey instrument includes two post-treatment questions that aim to tease out differences on these two dimensions.

The first question asks respondents to identify the appropriate time-horizon for the evaluation of foreign aid success, measured in number of years. I expect respondents from France, Japan, and Germany to indicate preferences for longer time horizons than their counterparts from the United States and Sweden. Subsequently, I ask respondents to identify the appropriate amount of state-strengthening out of all aid, choosing among answers including "none," "some," "quite a bit," "a large amount," and "all." I expect respondents from France, Japan, and Germany to exhibit a preference for more state-building aid, while I expect respondents from the United States and Sweden to exhibit less thereof.

[Table 3 here]

Table 3 presents the results of simple differences. Consistent with my expectations, the mean number of years considered appropriate for showing the success of aid efforts is lower among officials from the United States and Sweden, 4.56 years -indicating that their time horizons are significantly shorter than those among officials from France, Japan, and Germany which exhibit a mean of 6.27 . The difference of 1.71 years is statistically significant at the 0.01 
level. Further, statistically significant differences exist between political economy types when respondents indicate their preferences for state-building. A value of 5 indicates that "all" aid should be directed towards capacity building. Officials from the United States and Sweden how a mean of 3, while their French, Japanese, and German counterparts show a higher mean of 3.76. The 0.76 difference is statistically significant at the 0.01 level. These results buttress my claim that the differences in public sector governance shape donor governments' aid delivery preferences abroad.

While I treat national orientations as exogenous in this paper, I acknowledge that national orientations are not fixed. In the 1990s, in response to severe economic crises, the Scandinavian countries political-economic worldviews changed from statist to neoliberal in service provision. While data limitations preclude me from estimating a cross-national empirical model that evaluates within-donor variation in aid delivery, interview and survey evidence with Swedish donor officials suggests that Sweden's shift toward market-oriented public goods delivery is reflected in foreign aid decision-making. A former senior government officials offers pointed support for this expectation: "Swedish aid policy today stresses results-based management, and therefore resembles British aid policy a lot more than it used to in the 1980s or 1990s. Results-orientation starts under the Social Democrats in the wake of the real estate crisis in the 1990s when the government begins to liberalize the economy to enhance the efficiency of the welfare state. The budget is tight and there is pressure on the government to justify the aid expense. But resultsorientation is by no means unique to foreign aid. When you look at other policy areas such as the social transfer system, education, and child care you see similar practices. Today we have an open market in all areas of public goods in Sweden, and the Ministry of Foreign Affairs is developing a so-called "results-based strategy" for foreign aid. They want to make results more visible to the taxpayer. They want results in the short-term." ${ }^{79}$ I evaluated this claim using my sample of 13 Swedish aid officials. Eleven out of thirteen respondents suggested that timehorizons in aid evaluation had shrunk over the last twenty years ${ }^{80}$ and 10 out of 13 respondents suggested that there currently is less emphasis on state-strengthening than there was twenty years ago.

\footnotetext{
${ }^{79}$ Author interview with former senior government official, Ministry of Foreign Affairs, Stockholm, June 17, 2013. See also Bjerninger 2013

${ }^{80}$ The question offered a three-fold choice between "smaller," "same," and "greater" time horizons compared to what their answer was for the present.
} 


\section{Discussion and Conclusion}

This study developed and tested a model of endogenous aid delivery that accounts for heterogeneity in donor delivery preferences. The origins of donor officials' baseline delivery preferences are based on one important feature of the political economy: the role of the state in goods and service delivery. I argue that donor governments whose political economies emphasize marketbased delivery systems are more likely to pursue bypass tactics in poorly governed countries to circumvent aid capture by corrupt elites. As expected I find this prediction to hold for classic neoliberal political economies as well as for Scandinavian economies. Less market-oriented delivery systems are expected to bypass less in poor governance environments. Since their core orientation favors a stronger role of the government in the delivery of public sector goods, information about recipient governance will trigger some but not big movements away from the core orientation. I find statistical support for this prediction. This study thus provides robust evidence for a prominent research tradition in international relations that studies the domestic politics of foreign economic policy.

This study informs the aid effectiveness literature as it establishes a link between political economies and the different kinds of benchmarks that donor officials use to assess aid success. Donor governments that outsource aid delivery in countries with bad governance may achieve greater success in providing immediate relief to the poor through easily implementable health interventions than donor governments that continue to engage in institution-building in collaboration with the state. However, outsourcing in foreign aid delivery might hamper or even undermine donor efforts to build up a state capable of managing its own development -an objective which ranks high for donor governments that prefer a tactic of greater engagement with the government in the developing country. While donors often offer a combination of short- and long-term approaches the results of this study imply that political economies may shape where donors governments come in on this fundamental dilemma in aid provision.

My study also sheds light on potential trade-offs between aid effectiveness and policy influence. By setting up parallel structures, market-oriented donor governments may achieve greater success in providing direct relief to the poor. However, this approach may bring some unintended consequences. By de-emphasizing state-building donor governments may surrender the opportunity to strengthen relationships with state and local authorities. This may undermine donor ability to more directly shape policy and governance processes in aid-receiving countries. This potential dilemma merits further study.

My argument has implications for research that explains donor coordination -a practice 
encouraged by the OECD, on which little progress has been made. ${ }^{81}$ If differences in national orientations about the role of the state in goods and service provision make donor coordination difficult, then we should only expect countries with similar political economies to be able to coordinate successfully. This presents an interesting area for future research.

This study lays the groundwork for an extension that examines how national orientations evolve over time and, consequently, affect temporal variation in aid policy within donor countries. While national orientations -much like domestic structures- are "sticky," they are a product of politics where political parties renegotiate views about the appropriate role of the state in public goods delivery. ${ }^{82}$ If, as commonly done, we associate conservative parties with demands for more market-orientation in service provision, then we should expect a conservative government to push for more performance-oriented aid delivery tactics. Anecdotal evidence lends support for this initial contention. Recent victories of conservative parties in market-oriented political economies, including Canada (2006), Sweden (2007), and the United Kingdom (2010) have led to reforms in the delivery of foreign aid. These reforms emphasize primarily efficiency criteria. The British conservatives make this case in their party's green paper in 2009: "We [the conservative party, added by author] are absolutely clear that, as taxpayers feel the pinch, maintaining public support for our aid programme will require a much greater focus on performance, results and outcomes. Our bargain with taxpayers is this: in return for your contribution of hard-earned money it is our duty to spend every penny of aid effectively. [...] We bring a natural scepticism about government schemes. In many developing countries, supporting the state means supporting a particular group or tribe. Labour sometimes give aid directly to governments without adequate scrutiny." ${ }^{83}$ In a similar vein, Sweden's conservative government alliance emphasizes performance- and results-orientation, as do conservative parties in Australia, Canada, and their pendants in other OECD countries. If conservative political party ideology amplifies market-oriented tactics in public goods provision then we should expect more outsourcing in aid under conservative governments than governments of the left. Whether exogenous changes in government affect aid delivery tactics therefore demands further inquiry.

Finally, this study may encourage future research that explores how ideas dovetail with interests. My argument, as presented above, centers on the role of beliefs about the appropriate role of the state in service delivery in foreign aid decision-making. Another way of thinking about the role of ideas in aid delivery is that, over time, ideas about the appropriate role of the state in

\footnotetext{
${ }^{81}$ Easterly and Pfütze 2008; Winters 2012; Steinwand Forthcoming.

${ }^{82}$ See Lancaster 2006 and Lake 2013 for a discussion on the dynamic nature of domestic structures.

${ }^{83}$ Tories' Policy Green Paper 2009.
} 
service delivery facilitate the creation and organization of particular bureaucratic structures. ${ }^{84}$ These structures, in turn, generate domestic political interests and capabilities that get further accentuated in foreign policy. ${ }^{85}$ In foreign aid, the introduction of markets in foreign aid delivery resulted a reduction of capacity of the aid bureaucracy. Prior to the 1980s, the US government, through its main aid agency USAID, largely produced design and expertise in-house, sending many people abroad. In the 1980s the US government turned to markets which resulted in a significantly weaker bureaucracy in terms of number of employees and expertise. Today, USAID staff largely assumes managerial functions. ${ }^{86}$ It acts as a principal whose objectives are to find the best agent in order to implement aid effectively. Sida in Sweden has experienced similar changes. On the other hand, more "statist" beliefs, have facilitated the persistence of strong bureaucratic structures that enable governments to directly implement foreign aid using in-house capacity and expertise, or by relying on long-institutionalized relationships with nonstate service providers. In France, the AFD (Agence Française de Développement) has extensive in-house capacity for aid policy design and implementation as well as extensive field presence in nearly all the countries to whom the French government gives aid. Unlike USAID, the AFD serves as the primary agent for the delivery of French aid. In both types of donor political economies, ideas serve as true causal priors that affect the type of bureaucratic structures - and whether the bureaucracy assumes the role of principal or agent. With these different types of structures come particular sets of public and private domestic interests that seek to perpetuate existing systems of delivery. These, interests, in turn, contribute to explaining the divergence over the way that the U.S. and France do aid over the course of the last 50 years. I leave it up to future research to develop an argument of donor variation in aid delivery that weaves together ideational and interest-based explanations.

\footnotetext{
${ }^{84}$ e.g. Suleiman 2003 explores the effect of public sector reforms on the structure of bureaucracies.

${ }^{85}$ This view is consistent with Max Weber who suggested that "Not ideas, but material and ideal interests, directly govern men's conduct. Yet very frequently, the "world images" that have been created by ideas have, like switchmen, determined the tracks along which action has been pushed by the dynamic of interest." in "Social Psychology of the World's Religions" p.280; cited in Goldstein and Keohane 1993.

${ }^{86}$ However, recent reforms under the Obama administration have led to an increase in personnel and capacity.
} 


\section{References}

Andersen, Torben M., Bengt Holmstrom, Seppo Honkapohja, Sixten Korkman, Hans Tson Soderstrom, and Juhana Vartiainen. 2007. The Nordic Model: Embracing Globalization and Sharing Risks. Helsinki: Taloustieto Oy.

Ansell, Ben. 2010. From the Ballot to the Blackboard: The Redistributive Political Economy of Education Cambridge: Cambridge University Press.

Bennett, Scott D., and Allan Stam. 2000. EUGene: A Conceptual Manual. International Interactions 26:179-204.

Bertoli, Simone, Giovanni A. Cornia, and Francesco Manaresi. 2008. Aid Effort and Its Determinants: A Comparison of the Italian Performance with other OECD Donors, Unpublished Manuscript.

Bueno de Mesquita, Bruce, and Alastair Smith. 2009. A Political Economy of Foreign Aid. International Organization 63 (2):309-340.

Bertelli, Anthony M. 2012. The Political Economy of Public Sector Governance. Cambridge: Cambridge University Press.

Bjerninger, Jan. 2013. Det framgngsrika bistndet : om svenskt utvecklingssamarbete i praktiken. Hftad, Svenska, 2013.

Bold, Tessa, Mwangi Kimenyi, Germano Mwabu, Alice Ng'ang'a and Justin Sandefu. 2013. Scaling-up What Works: Experimental Evidence on External Validity in Kenyan Education. Unpublished Manuscript

Breuning, Marijke. 1995. Words and Deeds: Foreign Assistance Rhetoric and Policy Behavior in the Netherlands, Belgium, and the United Kingdom. International Studies Quarterly 39(2): $235-54$.

Boutton, Andrew T. and David B. Carter. Forthcoming. Fair Weather Allies: Terrorism and the Allocation of United States Foreign Aid. Journal of Conflict Resolution.

Bush, Sarah. 2013. The Taming of Democracy Assistance. Unpublished Manuscript. 
Chong, A. and M. Gradstein. 2008. What Determines Foreign Aid? The Donors' Perspective. Journal of Development Economics 87(1).

Cohen, Gary B., Ben W. Ansell, Robert H. Cox, and Jane Gingrich. 2011. Social Policy in the Smaller European States Oxford: Berghan Books.

Duflo, Esther, Pascaline Dupas and Michael Kremer. 2012. School Governance, Teacher Incentives, and Pupil-Teacher Ratios: Experimental Evidence from Kenyan Primary Schools. NBER Working Paper 17939.

Easterly, William, and Tobias Pfütze. 2008. Where Does the Money Go? Best and Worst Practices in Foreign Aid. Journal of Economic Perspectives 22(2)

Esteve-Abe, Margarita, Torben Iversen, and David Soskice. 2001. Social Protection and the Formation of Skills: A Reinterpretation of the Welfar State. in: Hall, Peter, and David Soskice (eds.) Varieties of Capitalism: The Institutional Foundations of Comparative Advantage Oxford: Oxford University Press: 145-183

Evans, Peter. 1995. Embedded Autonomy. States and Industrial Transformation. Princeton: Princeton University Press.

Ferlie, E., Ashburner, L, Fitzgerald, L, and Andrew Pettigrew. 1996. New Public Management in Action Oxford: Oxford University Press.

Flores, Thomas Edward, and Irfan Nooruddin. 2009. "Democracy Under the Gun: Understanding Post-Conflict Economic Recovery." Journal of Conflict Resolution 53(1): 3-29.

Flores, Thomas Edward, and Irfan Nooruddin. 2012. "The Effect of Elections on Post-Conflict Peace and Reconstruction." Journal of Politics 73(2): 558-570.

Gingrich, Jane. 2011. Making Markets in the Welfare State. Cambridge: Cambridge University Press.

Green, Donald, Soo Yeon Kim, and David Yoon. 2001. "Dirty Pool." International Organization 55(2):441-468.

Franzese, Robert J. 2002. Macroeconomic Policies of Developed Democracies. Cambridge: 
Cambridge University Press.

Gleditsch, Nils Petter, Peter Wallensteen, Mikael Eriksson, Margareta Sollenberg, and Hvard Strand. 2002. "Armed Conflict 19462001: A New Dataset." Journal of Peace Research 39 (5):615-637.

Gourevitch, Peter A. 1986. Politics in Hard Times: Comparative Responses to International Economic Crises. Ithaca: Cornell University Press.

Hall, Peter, and David Soskice (Eds.) 2001. Varieties of Capitalism: The Institutional Foundations of Comparative Advantage Oxford: Oxford University Press.

Hefeker, Carsten, and Katharina Michaelowa. 2005. Can Process Conditionality Enhance Aid Effectiveness? The Role of Bureaucratic Interests and Public Pressure. Public Choice 122(1): 15975 .

International Monetary Fund (IMF). 2011. Direction of Trade Statistics." Available from http://www2.imfstatistics.org/DOT/. Accessed 1 December 2009.

Jablonski, Ryan. Forthcoming. How Aid Target Votes: The Effect of Electoral Strategies on the Distribution of Foreign Aid. World Politics

Kaufman, Daniel, Aart Kraay, and Massimo Mastruzzi. 2011. Governance Matters VI.” Available from http://info.worldbank.org/governance/wgi/index.asp. Accessed 9 January 2012.

Katzenstein, Peter J. 1985. Small States in World Markets: Industrial Policy in Europe. Ithaca: Cornell University Press.

Katzenstein, Peter J. 1978. Between Power and Plenty: Foreign Economic Policies of Advanced Industrialized States. Madison: University of Wisconsin Press.

Knack, Stephen. 2013a. "Proliferation of Earmarked Contributions to Multilateral Donors." Unpublished Manuscript.

Knack, Stephen. 2013b. Building or Bypassing Recipient Country Systems: Are Donors Defying the Paris Declaration? World Bank Policy Research Working Paper 6423.

Kono, Daniel Y., and Gabriella R. Montinola. 2009. Does Foreign Aid Support Autocrats, 
Democrats, or Both? Journal of Politics 71 (2):704-718.

Kuziemko, Hyana, and Eric Werker. 2009. How Much is a Seat on the Security Council Worth? Foreign Aid and Bribery at the United Nations. Journal of Political Economy 114 (5):905-930.

Lake, David. A 2009. Open Economy Politics: A Critical Review. Review of International Organizations 4: 219-244.

Lake, David. A. 2013. Crises of Authority: Domestic Structures and the Changing American Imperium. Unpublished Manuscript.

Lancaster, Carol. 2006. Foreign Aid: Diplomacy, Development, Domestic Politics. Chicago, IL: University of Chicago Press.

Lumsdaine, David H. 1993. Moral Vision in International Politics: The Foreign Aid Regime, 19491989 Princeton, NJ: Princeton University Press.

Lundsgaarde, Erik. 2012. The Domestic Politics of Foreign Aid. New York: Routledge.

Mansfield and Jon Pevehouse. 2006. Democratization and International Organizations International Organization 60(1): 137-67.

Metcalf, Les, and Sue Richards. 1990. Improving Public Management, London: Sage Publications.

Milner, Helen. 1997. Interests, Institutions, and Information: Domestic Politics and International Relations. Princeton: Princeton University Press.

Milner, Helen. 2006. Why Multilateralism? Foreign Aid and Domestic Principal-Agent Problems. In Delegation and Agency in International Organizations, edited by Darren Hawkins, David Lake, Daniel Nielson, and Michael Tierney, p.107-139. Cambridge, MA: Cambridge University Press.

Milner, Helen and Dustin H. Tingley. 2010. The Political Economy of U.S. Foreign Aid: American Legislators and the Domestic Politics of Aid. Journal of Economics and Politics 22(2): 200-232.

Milner, Helen and Dustin H. Tingley. 2014. Sailing the Water's Edge: Where Domestic Politics 
Meets American Foreign Policy. Unpublished Manuscript.

Natsios, Andrew. 2010. The Clash of the Counter-bureaucracy and Development. Center for Global Development Essay. www.cgdev.org/content/publications/detail/1424271.

Nelson, Stephen C. 2014. "Playing Favorites: How Shared Beliefs Shape the IMF's Lending Decisions." International Organization 68(2): 297-328.

Organisation for Economic Cooperation and Development (OECD). 2008a. CRS Reporting Directives Manual. Available from http://www.oecd.org/dataoecd/.

Organisation for Economic Cooperation and Development (OECD). 2011. "National Accounts Database" Available from http://stats.oecd.org/Index.aspx?DataSetCode=NAAG. Accessed 14 March 2013.

Organisation for Economic Cooperation and Development (OECD). 2012. "Development Database on Aid Activities: CRS." Available from http://stats.oecd.org. Accessed 14 January.

Osborne, David, and Ted Gaebler. 1992. Reinventing Government.

Peterson, Paul. 1994. "The Presidents Dominance in Foreign Policymaking. Political Science Quarterly 109: 21534.

Quinn, Dennis P. and Carla Inclan. 1997. The Origins of Financial Openness: A Study of Current and Capital Account Liberalization. American Journal of Political Science 41(3): 771813

Radelet, Steven. 2004. "Aid Effectiveness and the Millenium Development Goals." Working Paper 39. Washington, D.C: Center for Global Development.

Simmons, Beth A. 1994. Who Adjusts: Domestic Sources of Foreign Economic Policy During the Interwar Years. Princeton: Princeton University Press.

Steinmo, Sven. 2010. The Evolution of Modern States: Sweden, Japan, and the United States.

Steinwand, Martin. Forthcoming. Compete or Coordinate? Aid Fragmentation and Lead Donorship. International Organization 
Suleiman, Ezra. 1974. Politics, Power, and Bureaucracy in France: The Administrative Elite Princeton: Princeton University Press.

Suleiman, Ezra. 2003. Dismantling Democratic States. Princeton: Princeton University Press.

Sullivan, Terry. 1991. "A Matter of Fact: The Two Presidencies Thesis Revitalized." In The Two Presidencies: A Quarter Century Assessment, ed. Steven A. Shull. Chicago: Nelson-Hall, 14357

Svensson, Jakob. 2000. Foreign Aid and Rent-Seeking. Journal of International Economics 51(2): 437-461.

Therien, Jean-Phillippe and Alain Noel. 2000. Political Parties and Foreign Aid. American Political Science Review 94 (1):151-162.

Tanzi, Vito. 2011. Government versus Markets: The Changing Role of the State. Cambridge: Cambridge University Press.

Van der Veen, Maurits. 2011. Ideas, Interests, and Foreign Aid. Cambridge: Cambridge University Press.

Volkov, Boris B. and Michelle E. Baron. 2011. Internal Evaluation in the 21st Century: New Directions for Evaluation. Wiley and Sons.

Wildavsky, Aaron. 1998. "The Two Presidencies." Society 35(2): 23-31.

Winters, Matthew. Forthcoming. Targeted Aid and Capture in World Bank Projects. International Studies Quarterly

Winters, Matthew. 2012. The Obstacles for Foreign Aid Harmonization: Lessons from Decentralization Support in Indonesia. Studies in Comparative International Development 47(3): $316-41$.

Wooldrige, Jeffrey. 2002. Econometric Analysis of Cross Section and Panel Data. Cambridge, MA: MIT Press.

World Bank. 2011. World Development Indicators. Washington, DC: World Bank. 
Wright, Joseph. 2009. How Foreign Aid Can Foster Democratization in Authoritarian Regimes.

American Journal of Political Science 53(3): 552-571. 


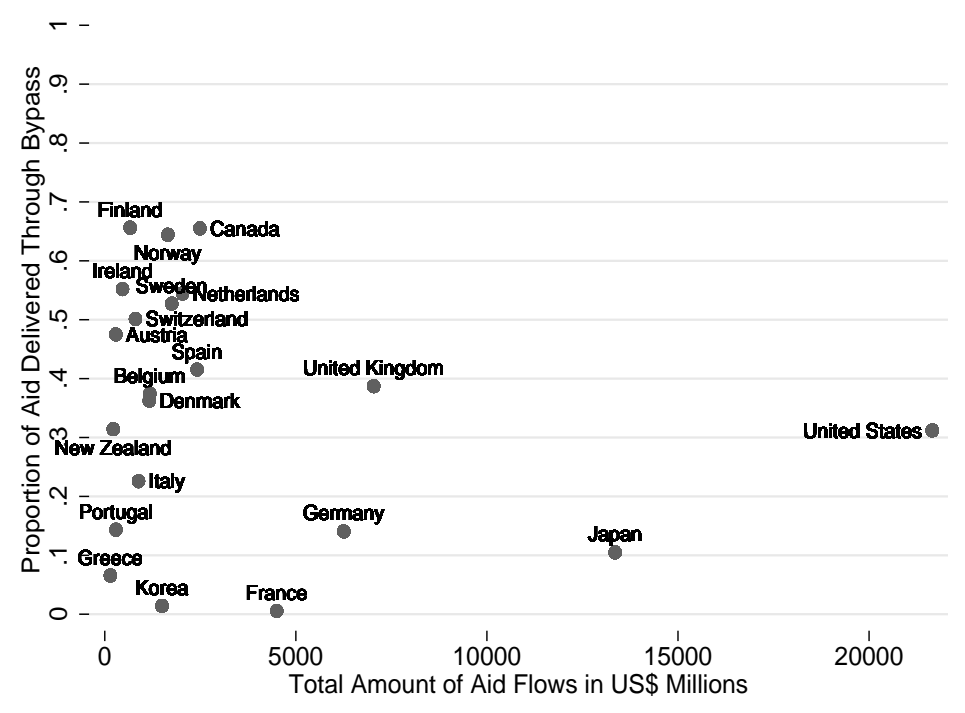

Figure 1: Proportion of Bypass Aid for 23 OECD Donors, 2009. Y-axis is fraction of aid delivered through non-state development actors (e.g. IOs, NGO, for-profit organizations). X-axis is total aid commitments in constant US\$ in millions. Source: OECD CRS Database (2013), and authors' calculation. 


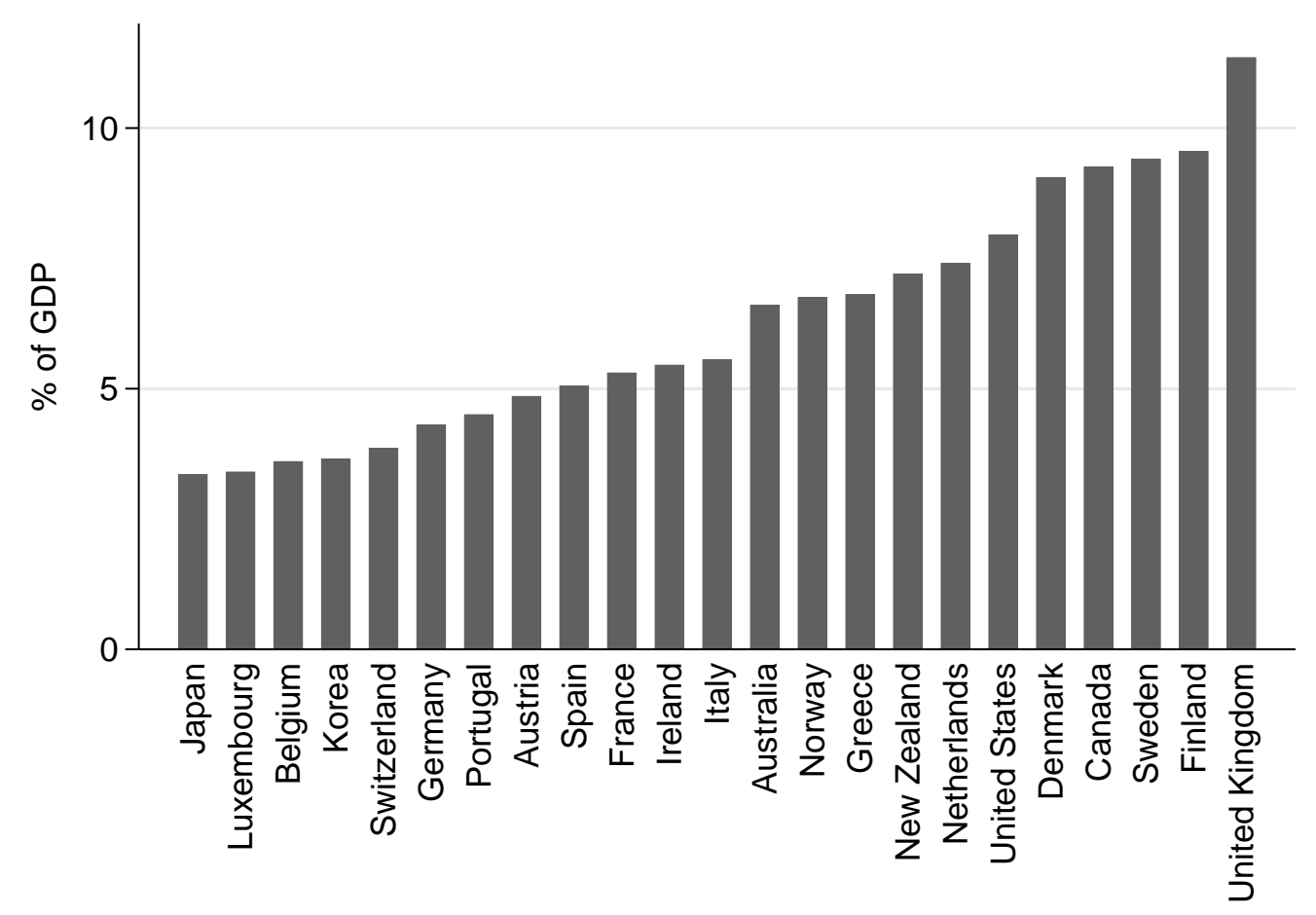

Figure 2: Domestic Government Outsourcing Across Individual Donors. Expenditures on government outsourcing to non-state actors for goods and services used by the government as percentage of GDP across donor countries in 2009. Source: OECD National Accounts Database (2011), and authors' calculation. 


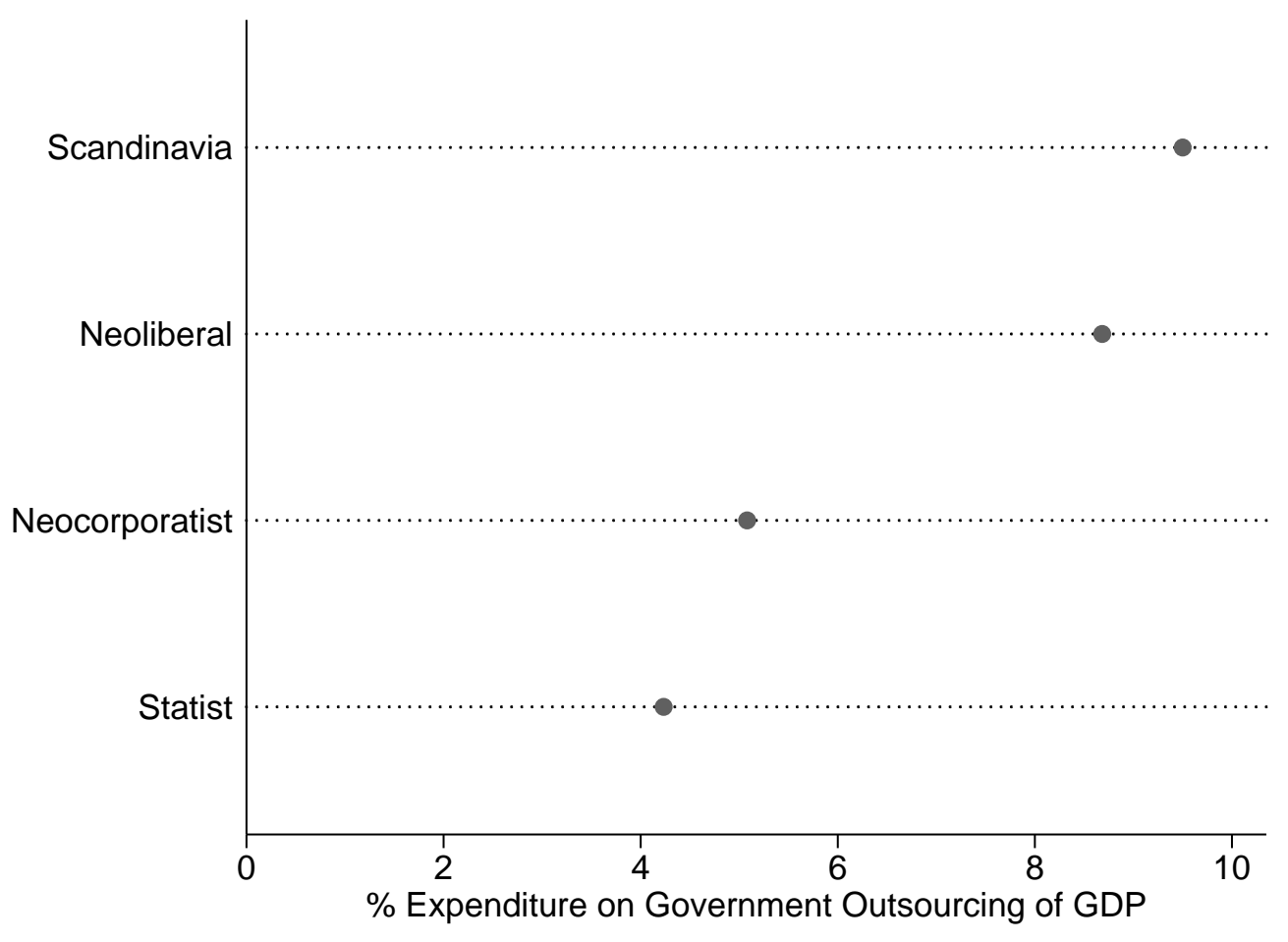

Figure 3: Domestic Government Outsourcing Across Individual Donors and Political Economies. Expenditures on government outsourcing to non-state actors for goods and services used by the government as percentage of GDP across political economy types in 2009. Source: OECD National Accounts Database (2011), and authors' calculation. 

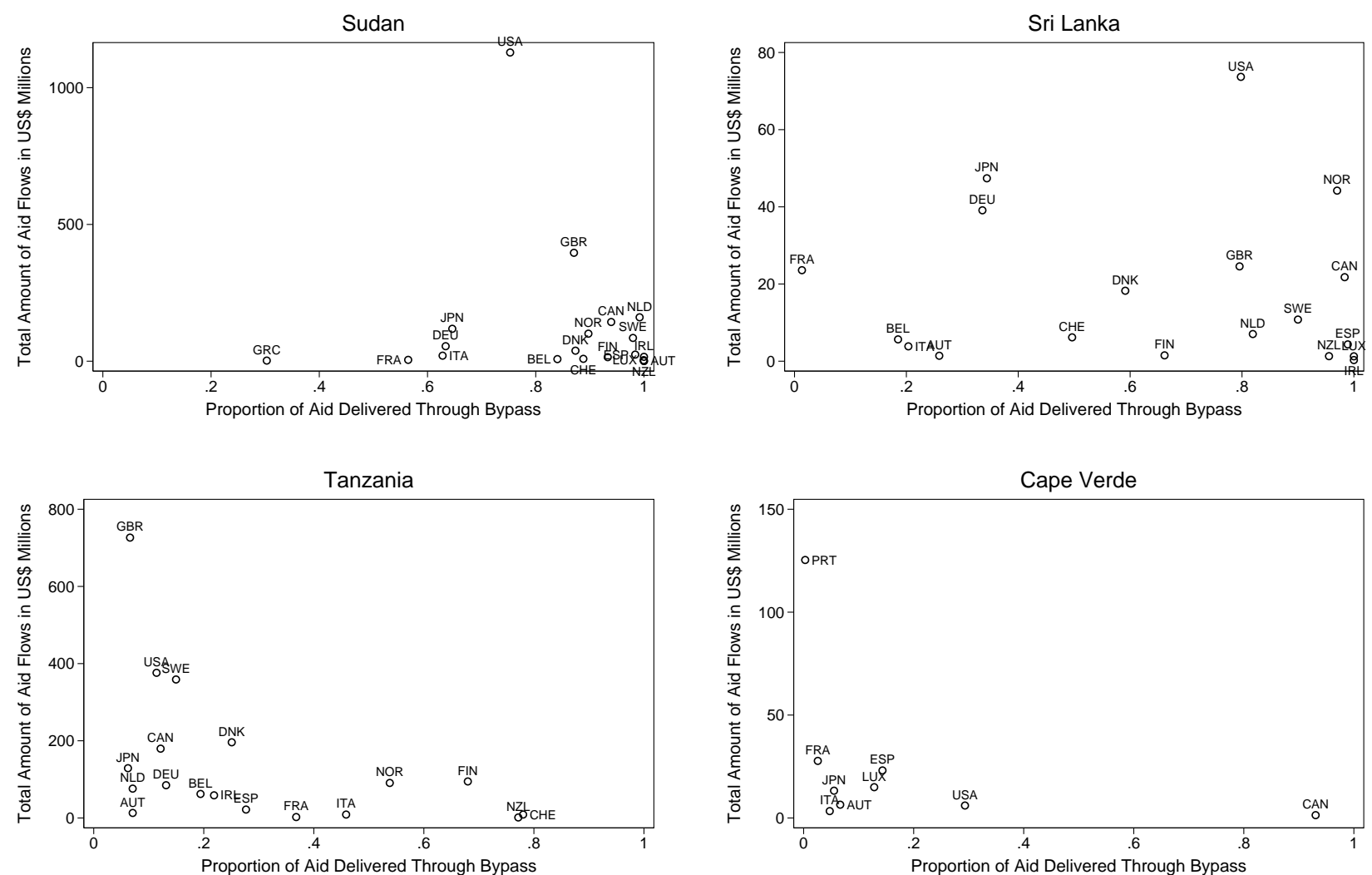

Figure 4: Proportion of Bypass Aid for OECD Donors in Select Recipient Countries, 2010. $Y$-axis is total aid commitments in constant US\$ in millions. X-axis is fraction of aid delivered through non-state development actors. Source: OECD CRS Database (2013), and authors' calculation. 
Binary Typology

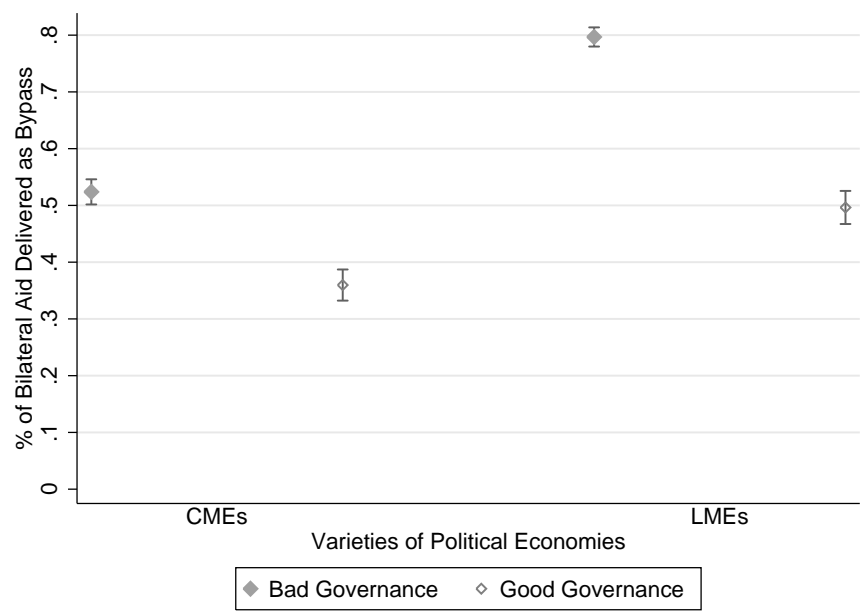

Four-Fold Typology

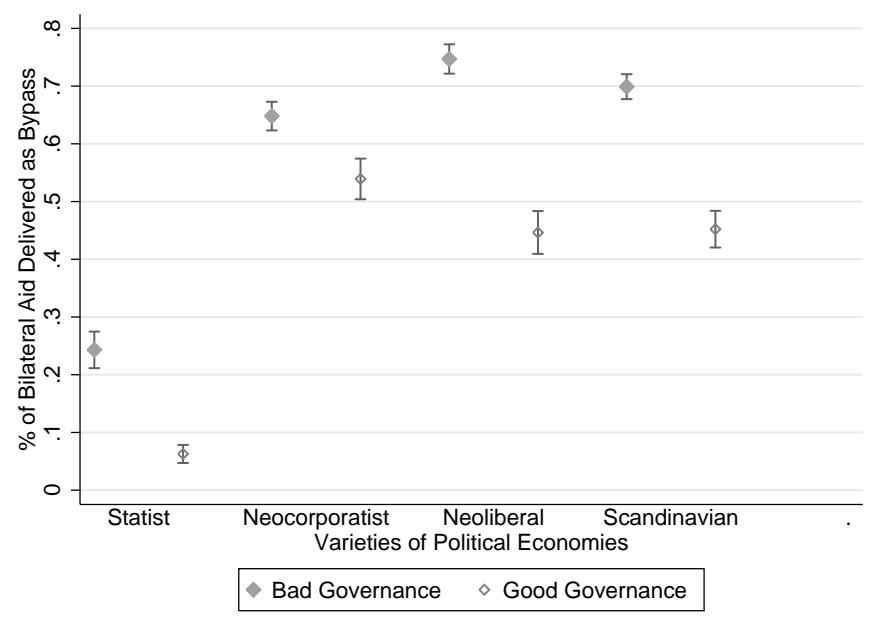

Figure 5: Donor Delivery Tactics by Political Economy Types, 2005-2011. Left panel shows aid delivery patterns for binary political economy division (CMEs and LMEs). Whisker plots show data range with 95\% confidence interval. Diamond-symbol of whisker plot represents average bypass share in badly governed countries, while square-symbol shows average bypass share in well-governed countries. Right panel shows same whisker plots for four-fold political economy typology (statist, neocorporatist, neoliberal, and Scandinavian). Source: OECD CRS Database (2013), and authors' calculation. 


\begin{tabular}{|c|c|c|c|c|c|c|c|c|}
\hline & Model 1 & Model 2 & Model 3 & Model 4 & Model 5 & Model 6 & Model 7 & Model 8 \\
\hline Lagged Bypass & & $\begin{array}{c}0.397^{* *} \\
(0.02)\end{array}$ & & $\begin{array}{c}0.506^{* *} \\
(0.01)\end{array}$ & & $\begin{array}{c}0.476^{* *} \\
(0.01)\end{array}$ & & $\begin{array}{c}0.528^{* *} \\
(0.01)\end{array}$ \\
\hline Recipient Governance & $\begin{array}{c}-1.621^{* *} \\
(0.31)\end{array}$ & $\begin{array}{c}-1.094^{* *} \\
(0.22)\end{array}$ & $\begin{array}{l}0.337 \\
(0.91)\end{array}$ & $\begin{array}{l}-0.119 \\
(0.94)\end{array}$ & $\begin{array}{l}0.301 \\
(0.91)\end{array}$ & $\begin{array}{c}-0.183 \\
(0.94)\end{array}$ & $\begin{array}{l}0.814 \\
(0.92)\end{array}$ & $\begin{array}{l}0.098 \\
(0.93)\end{array}$ \\
\hline LMEs*Rec Gov & & & $\begin{array}{c}-0.751^{*} \\
(0.38)\end{array}$ & $\begin{array}{l}-0.419 \\
(0.28)\end{array}$ & & & & \\
\hline LMEs & & & $\begin{array}{c}5.884^{* *} \\
(0.85)\end{array}$ & $\begin{array}{c}3.448^{* *} \\
(0.60)\end{array}$ & & & & \\
\hline CMEs*Rec Gov & & & $\begin{array}{l}0.400 \\
(0.44)\end{array}$ & $\begin{array}{l}0.263 \\
(0.29)\end{array}$ & & & & \\
\hline CMEs & & & $\begin{array}{l}1.716^{*} \\
(0.89)\end{array}$ & $\begin{array}{l}1.004 \\
(0.61)\end{array}$ & & & & \\
\hline Neoliberal*Rec Gov & & & & & $\begin{array}{c}-0.762^{*} \\
(0.42)\end{array}$ & $\begin{array}{c}-0.322 \\
(0.32)\end{array}$ & & \\
\hline Neoliberal & & & & & $\begin{array}{c}5.254^{* *} \\
(0.89)\end{array}$ & $\begin{array}{c}3.030^{* *} \\
(0.67)\end{array}$ & & \\
\hline Scandinavian*Rec Gov & & & & & $\begin{array}{l}-0.517 \\
(0.45)\end{array}$ & $\begin{array}{l}-0.455 \\
(0.32)\end{array}$ & & \\
\hline Scandinavian & & & & & $\begin{array}{c}5.048^{* *} \\
(0.99)\end{array}$ & $\begin{array}{c}3.397^{* *} \\
(0.67)\end{array}$ & & \\
\hline Statist*Rec Gov & & & & & $\begin{array}{l}0.803 \\
(0.49)\end{array}$ & $\begin{array}{l}0.482 \\
(0.38)\end{array}$ & & \\
\hline Statist & & & & & $\begin{array}{c}-3.396^{* *} \\
(1.07)\end{array}$ & $\begin{array}{c}-1.877^{* *} \\
(0.80)\end{array}$ & & \\
\hline Neocorporatist*Rec Gov & & & & & $\begin{array}{l}0.510 \\
(0.45)\end{array}$ & $\begin{array}{l}0.361 \\
(0.30)\end{array}$ & & \\
\hline Neocorporatist & & & & & $\begin{array}{c}2.766^{* *} \\
(0.90)\end{array}$ & $\begin{array}{c}1.551^{* *} \\
(0.63)\end{array}$ & & \\
\hline Govt Outsourcing/GDP*Rec Gov & & & & & & & $\begin{array}{c}-0.106^{*} \\
(0.06)\end{array}$ & $\begin{array}{r}-0.047 \\
(0.03)\end{array}$ \\
\hline Govt Outsourcing/GDP & & & & & & & $\begin{array}{c}0.416^{* *} \\
(0.13)\end{array}$ & $\begin{array}{c}0.262^{* *} \\
(0.07)\end{array}$ \\
\hline Democracy & $\begin{array}{c}-0.177^{*} \\
(0.09)\end{array}$ & $\begin{array}{c}-0.117^{*} \\
(0.07)\end{array}$ & $\begin{array}{l}-0.256 \\
(0.29)\end{array}$ & $\begin{array}{l}-0.215 \\
(0.29)\end{array}$ & $\begin{array}{l}-0.267 \\
(0.29)\end{array}$ & $\begin{array}{l}-0.224 \\
(0.30)\end{array}$ & $\begin{array}{l}-0.238 \\
(0.29)\end{array}$ & $\begin{array}{l}-0.196 \\
(0.29)\end{array}$ \\
\hline Natural Disaster Deaths & $\begin{array}{c}0.070^{* *} \\
(0.04)\end{array}$ & $\begin{array}{l}0.023 \\
(0.03)\end{array}$ & $\begin{array}{l}-0.009 \\
(0.03)\end{array}$ & $\begin{array}{c}-0.023 \\
(0.03)\end{array}$ & $\begin{array}{l}-0.005 \\
(0.03)\end{array}$ & $\begin{array}{l}-0.021 \\
(0.03)\end{array}$ & $\begin{array}{l}-0.008 \\
(0.03)\end{array}$ & $\begin{array}{c}-0.020 \\
(0.03)\end{array}$ \\
\hline Civil Conflict & $\begin{array}{c}0.785^{* *} \\
(0.25)\end{array}$ & $\begin{array}{c}0.484^{* *} \\
(0.19)\end{array}$ & $\begin{array}{l}0.208 \\
(0.27)\end{array}$ & $\begin{array}{l}-0.034 \\
(0.28)\end{array}$ & $\begin{array}{l}0.193 \\
(0.27)\end{array}$ & $\begin{array}{c}-0.047 \\
(0.27)\end{array}$ & $\begin{array}{l}0.172 \\
(0.29)\end{array}$ & $\begin{array}{l}-0.058 \\
(0.28)\end{array}$ \\
\hline Distance & $\begin{array}{l}0.179 \\
(0.21)\end{array}$ & $\begin{array}{l}0.036 \\
(0.18)\end{array}$ & $\begin{array}{c}-1.653^{* *} \\
(0.25)\end{array}$ & $\begin{array}{c}-1.206^{* *} \\
(0.17)\end{array}$ & $\begin{array}{c}-0.403^{*} \\
(0.23)\end{array}$ & $\begin{array}{c}-0.407^{* *} \\
(0.16)\end{array}$ & $\begin{array}{c}-0.814^{* *} \\
(0.24)\end{array}$ & $\begin{array}{c}-0.656^{* *} \\
(0.15)\end{array}$ \\
\hline Former Colony & $\begin{array}{l}0.434 \\
(0.32)\end{array}$ & $\begin{array}{l}0.252 \\
(0.22)\end{array}$ & $\begin{array}{c}2.889^{* *} \\
(0.71)\end{array}$ & $\begin{array}{c}1.543^{* *} \\
(0.68)\end{array}$ & $\begin{array}{c}2.838^{* *} \\
(0.72)\end{array}$ & $\begin{array}{c}1.511^{* *} \\
(0.68)\end{array}$ & $\begin{array}{c}2.732^{* *} \\
(0.71)\end{array}$ & $\begin{array}{c}1.362^{* *} \\
(0.68)\end{array}$ \\
\hline Trade Intensity & $\begin{array}{c}-0.104^{* *} \\
(0.04)\end{array}$ & $\begin{array}{c}-0.053^{*} \\
(0.03)\end{array}$ & $\begin{array}{c}-0.289^{* *} \\
(0.07)\end{array}$ & $\begin{array}{c}-0.143^{* *} \\
(0.04)\end{array}$ & $\begin{array}{c}-0.284^{* *} \\
(0.06)\end{array}$ & $\begin{array}{c}-0.143^{* *} \\
(0.04)\end{array}$ & $\begin{array}{c}-0.265^{* *} \\
(0.06)\end{array}$ & $\begin{array}{c}-0.128^{* *} \\
(0.04)\end{array}$ \\
\hline Security Council & $\begin{array}{c}-0.188 \\
(0.32)\end{array}$ & $\begin{array}{l}-0.163 \\
(0.21)\end{array}$ & $\begin{array}{r}-0.193 \\
(0.29)\end{array}$ & $\begin{array}{c}-0.153 \\
(0.21)\end{array}$ & $\begin{array}{r}-0.178 \\
(0.30)\end{array}$ & $\begin{array}{l}-0.136 \\
(0.21)\end{array}$ & $\begin{array}{r}-0.195 \\
(0.29)\end{array}$ & $\begin{array}{c}-0.134 \\
(0.21)\end{array}$ \\
\hline Total Aid per capita & $\begin{array}{c}-0.068^{* *} \\
(0.02)\end{array}$ & $\begin{array}{c}-0.074^{*} \\
(0.04)\end{array}$ & $\begin{array}{c}-0.114^{* *} \\
(0.02)\end{array}$ & $\begin{array}{c}-0.076^{*} \\
(0.04)\end{array}$ & $\begin{array}{c}-0.132^{* *} \\
(0.02)\end{array}$ & $\begin{array}{r}-0.058 \\
(0.04)\end{array}$ & $\begin{array}{c}-0.097^{* *} \\
(0.02)\end{array}$ & $\begin{array}{r}-0.016 \\
(0.05)\end{array}$ \\
\hline Social Sector Aid & $\begin{array}{c}-0.027^{* *} \\
(0.01)\end{array}$ & $\begin{array}{c}-0.015^{*} \\
(0.01)\end{array}$ & $\begin{array}{c}-0.029^{* *} \\
(0.01)\end{array}$ & $\begin{array}{l}-0.010 \\
(0.01)\end{array}$ & $\begin{array}{l}-0.010 \\
(0.01)\end{array}$ & $\begin{array}{l}-0.004 \\
(0.01)\end{array}$ & $\begin{array}{c}-0.044^{* *} \\
(0.01)\end{array}$ & $\begin{array}{c}-0.015^{*} \\
(0.01)\end{array}$ \\
\hline Democracy Aid & $\begin{array}{l}-0.005 \\
(0.01)\end{array}$ & $\begin{array}{l}-0.006 \\
(0.01)\end{array}$ & $\begin{array}{l}0.012 \\
(0.01)\end{array}$ & $\begin{array}{c}-0.007 \\
(0.01)\end{array}$ & $\begin{array}{l}0.014 \\
(0.01)\end{array}$ & $\begin{array}{l}-0.007 \\
(0.01)\end{array}$ & $\begin{array}{c}0.039 * * \\
(0.01)\end{array}$ & $\begin{array}{l}0.003 \\
(0.01)\end{array}$ \\
\hline Year & $\begin{array}{c}0.600^{* *} \\
(0.05)\end{array}$ & $\begin{array}{c}0.554^{* *} \\
(0.05)\end{array}$ & & & & & & \\
\hline Major Power & & & $\begin{array}{c}-2.573^{* *} \\
(0.21)\end{array}$ & $\begin{array}{c}-0.820 * * \\
(0.16)\end{array}$ & $\begin{array}{c}-1.693^{* *} \\
(0.19)\end{array}$ & $\begin{array}{c}-0.679^{* *} \\
(0.15)\end{array}$ & $\begin{array}{c}-2.518^{* *} \\
(0.22)\end{array}$ & $\begin{array}{c}-0.812^{* *} \\
(0.16)\end{array}$ \\
\hline $\mathrm{R}$ squared & 0.358 & 0.476 & 0.221 & 0.441 & 0.262 & 0.454 & 0.190 & 0.433 \\
\hline $\mathrm{N}$ & 10605 & 8760 & 10605 & 8760 & 10605 & 8760 & 10605 & 8760 \\
\hline
\end{tabular}

Table 1: Donor Political Economy and Bypassing Governments in AidReceiving Countries, 2005-2011. $* p<0.10, * * p<0.05, * * * p<0.01$. Constant (all columns) not reported; region dummies for Sub-Saharan Africa, Latin-America, Middle East, Asia and Eastern Europe as omitted category (Models 1,2) are not reported; donor fixed effects (Models 1 and 2); year fixed effects (Models 3 to 8); recipient fixed effects (Models 3 to 8) 
Binary Typology

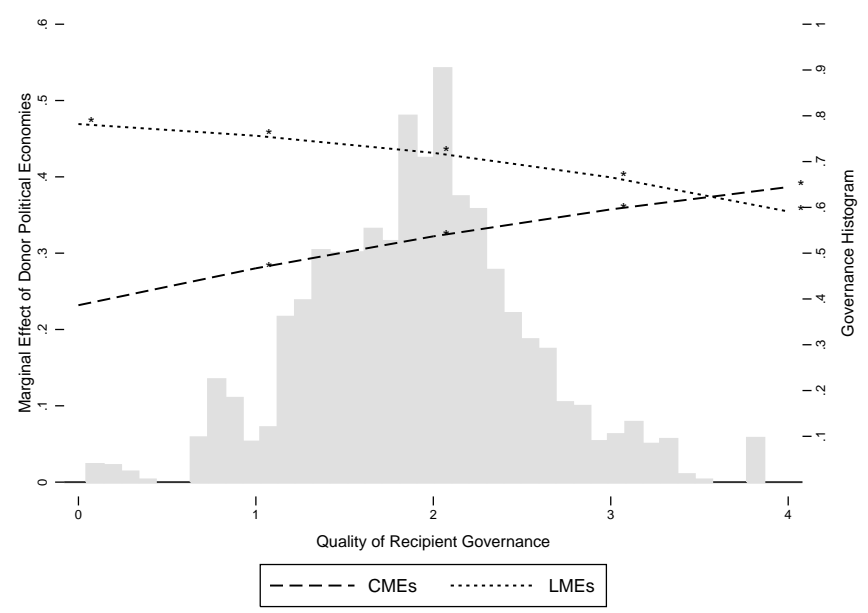

Four-Fold Typology

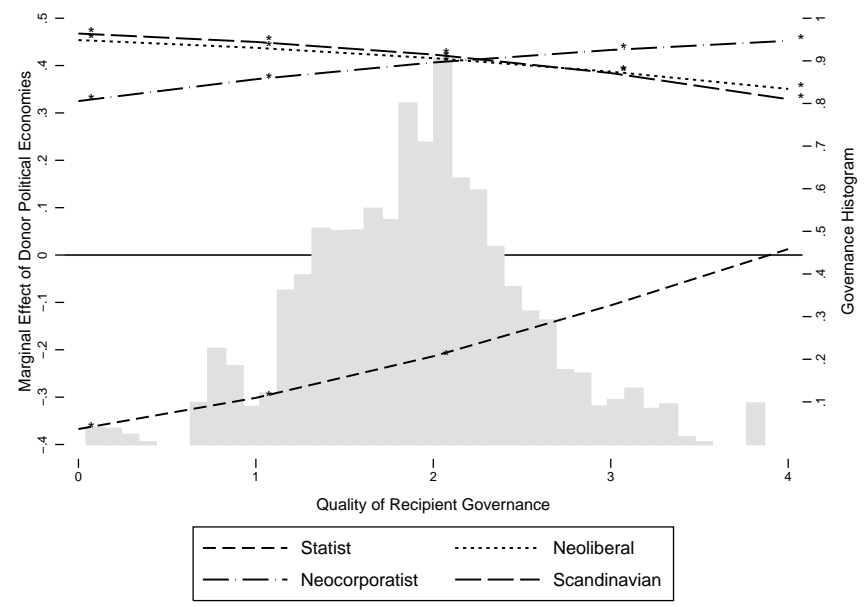

Figure 6: Marginal Effects of Political Economy Types Across Quality of Recipient Governance. Left panel: effects of binary political economy division estimated by Model 4. Right panel: effects of four-fold political economy division estimated by Model 6. Stars signal statistical significance at 0.05 level from from the omitted "other" category (Spain, Portugal, and Greece), but not from each other. Sources: OECD CRS Database (2013), and authors' calculation. 


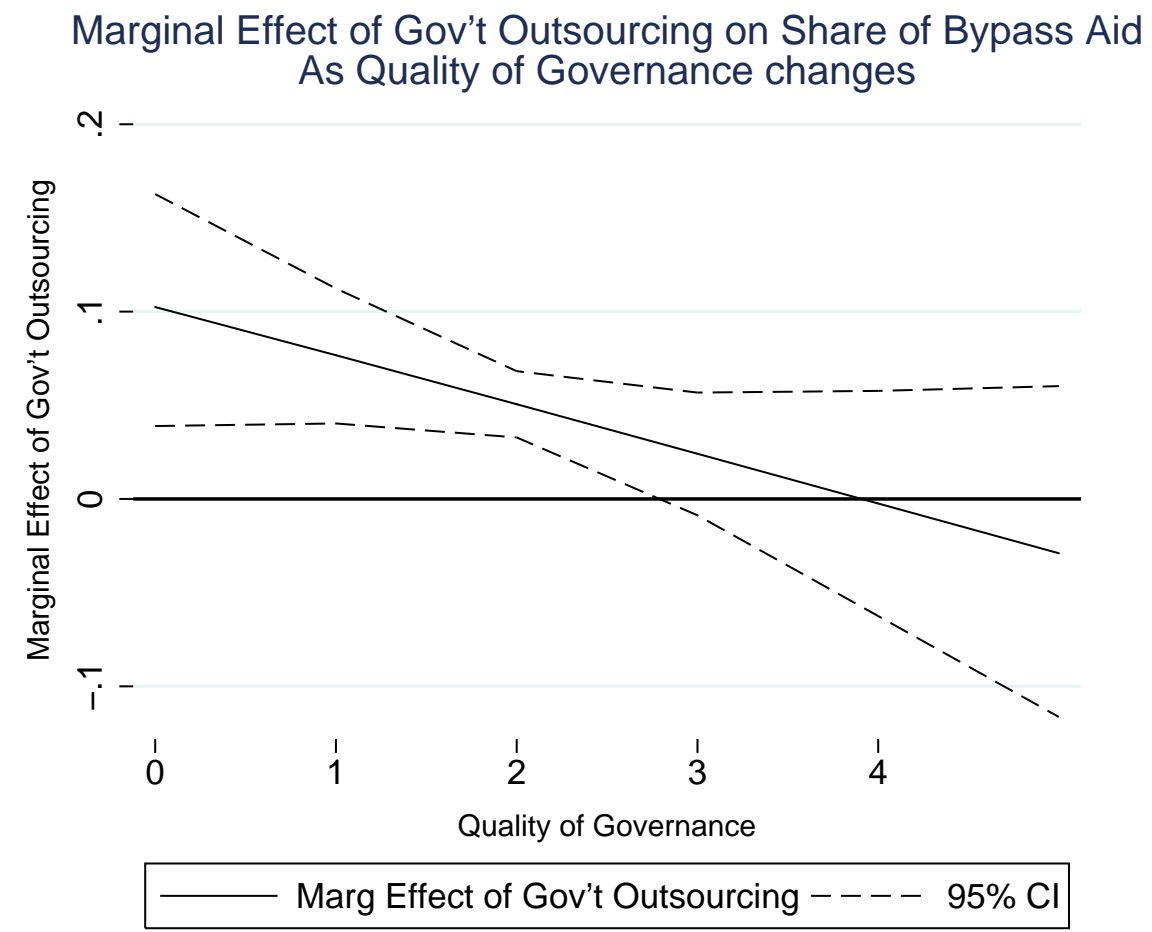

Figure 7: Marginal Effect of Government Outsourcing on Bypass Share Across Quality of Recipient Governance. Sources: OECD CRS Database (2013), OECD National Accounts Database (2011), and authors' calculation. 
Ranking Measure
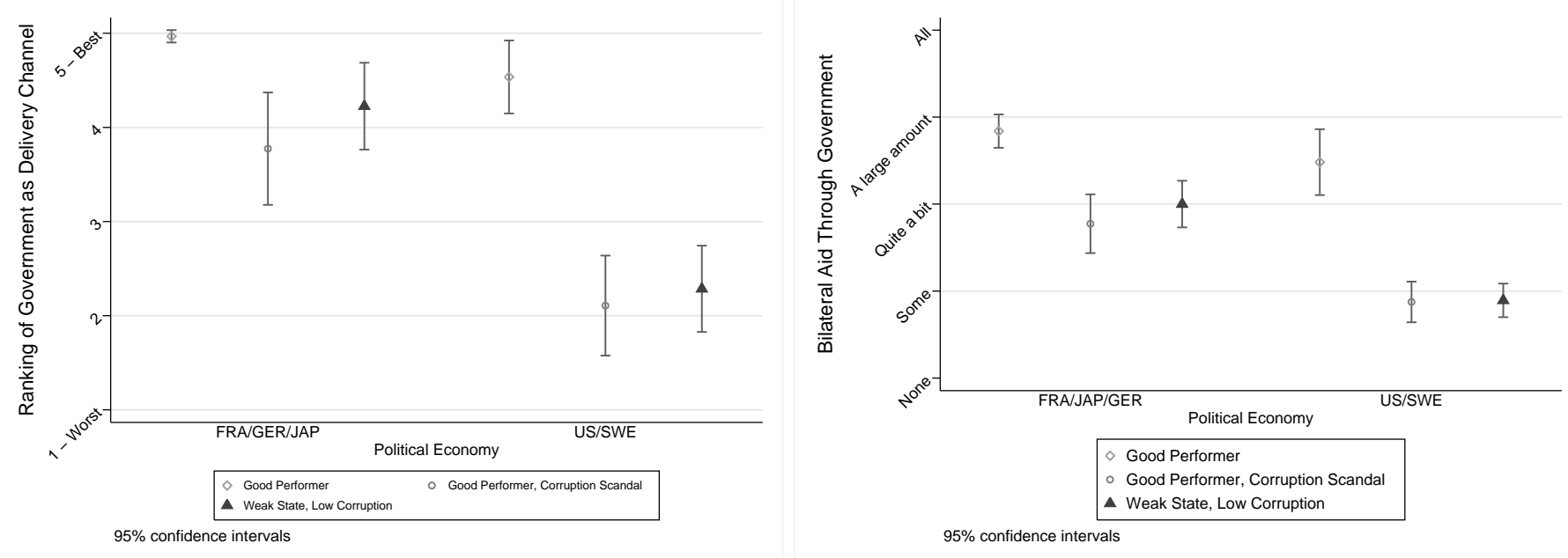

Figure 8: Point Estimates and 95\% Confidence Intervals for "No Bypass" Aid Delivery Rank-Order and "No Bypass" Share of All Bilateral Aid by Donor Political Economy Across Governance Scenarios. Left Panel: "No Bypass" rankorder measure. Right Panel: "No Bypass" share measure. Country A: Good Performer, Country B: Weak State Institutions, Low Corruption, Country C: Good Performer, Corruption Scandal. Source: Survey data of senior aid officials from France, Germany, Japan, United States, and Sweden. 


\begin{tabular}{lcc}
\hline \hline & Country A to B & Country A to C \\
& Diff-in-Diff & Diff-in-Diff \\
\hline No Bypass -Ranking & $-1.51^{* * *}$ & $-1.24^{* * *}$ \\
Std. Error & 0.37 & 0.43 \\
R square & 0.51 & 0.46 \\
\hline No Bypass -Proportion & $-0.75^{* * *}$ & $-0.54^{* * *}$ \\
Std. Error & 0.26 & 0.29 \\
R square & 0.52 & 0.49 \\
\hline \hline
\end{tabular}

Table 2: Difference-in-Difference Estimates Of Aid Delivery Ranking by Donor Political Economy. $* p<0.10, * * p<0.05, * * * p<0.01$. In the top half of the table, respondents evaluate Country A (Good Performer), followed by Country C (Corruption Scandal). In the lower half of the table, respondents evaluate Country A (Good Performer), followed by Country C (Weak State Institutions) "No Bypass -Ranking" is based on rankorder of aid delivery preferences - "5" indicating recipient government is first choice. "No Bypass -Proportion" is based on proportional measure for aid delivery preferences - "5" indicating all aid should go through the recipient government. Source: Survey Data of Senior Aid Officials from France, Germany, Japan, United States, and Sweden 


\begin{tabular}{lcccccc}
\hline \hline & $\mathrm{N}$ & Mean & Std. Err. & Diff. & t-stat & p-value \\
\hline Time Horizon - FRA/GER/JAP & 31 & 6.33 & 0.44 & & & \\
Time Horizon - USA/SWE & 26 & 4.81 & 0.41 & 1.52 & 2.49 & 0.01 \\
\hline State-Building Efforts - FRA/GER/JAP & 31 & 3.74 & 0.09 & & & \\
State-Building Efforts - USA/SWE & 26 & 3.03 & 0.13 & 0.71 & 4.51 & 0.00 \\
\hline
\end{tabular}

Table 3: Simple T-test Results Of Time Horizon Associated with Aid Success and Importance of State-building Efforts as Share of Overall Efforts. "Time Horizon" captures number of years after which respondents measure success of foreign aid. "State-Building Efforts" captures the ratio of aid allocated towards state-building versus direct aid - "5" indicating all aid should be used to build state capacity and no aid should be allocated for direct relief purposes. Source: Survey data of senior aid officials from France, Germany, Japan, United States, and Sweden 


\section{APPENDIX}

\section{Compositional Data Analysis}

This section provides a brief discussion of the statistical implications of using a proportional outcome measure, which requires compositional data analysis. For any donor-recipient dyad the aid channel share is positive and the sum of the aid channels shares must be one hundred percent. Consider the aid share A, in donor-recipient dyad i for channel $j$. The compositional nature of the variable is expressed by the constraints that the fraction of the aid share that government-togovernment or non-state channels might receive is doubly bounded, falling between 0 and 1 ,

$$
A_{i, j} \in[0,1] \quad \forall i, j,
$$

with $A_{i, j}$ denoting the fraction of the aid in donor-recipient dyad i $(\mathrm{i}=1, \ldots, \mathrm{N})$ for delivery channel $\mathrm{j}(\mathrm{j}=1, \mathrm{~J})$. Government-to-government aid and non-state aid in a given donor-recipient dyad sums to unity,

$$
\sum_{j=1}^{J} A_{i j}=1 \quad \forall i, j,
$$

where $J$ is the total number of delivery channels, which equal 2 (government-to-government and non-state aid) in my case.

Following Aitchison (1986), I create a $(J-1) \log$ aid ratio, which compares the non-state aid to government-to-government aid:

$$
Y_{i 1}=\ln \left(A_{i 1} / A_{i 2}\right)=\ln \left(A_{i 1} /\left(1-A_{i 1}\right)\right.
$$

The advantage of log transforming proportional outcomes is that the outcome is unconstrained, allowing for a straightforward estimation through OLS. The coefficient of the log-transformed nonstate share variable then describes how the log ratio of non-state aid changes with respect to government-to-government aid. After modeling, the estimates are transformed back into their original scale of interest:

$$
A_{i 1}=\left(1+e^{-} Y_{i 1}\right)^{-1} \text {. }
$$

and $\mathrm{Y}$ is log-transformed following the steps (1) through (4) above. 


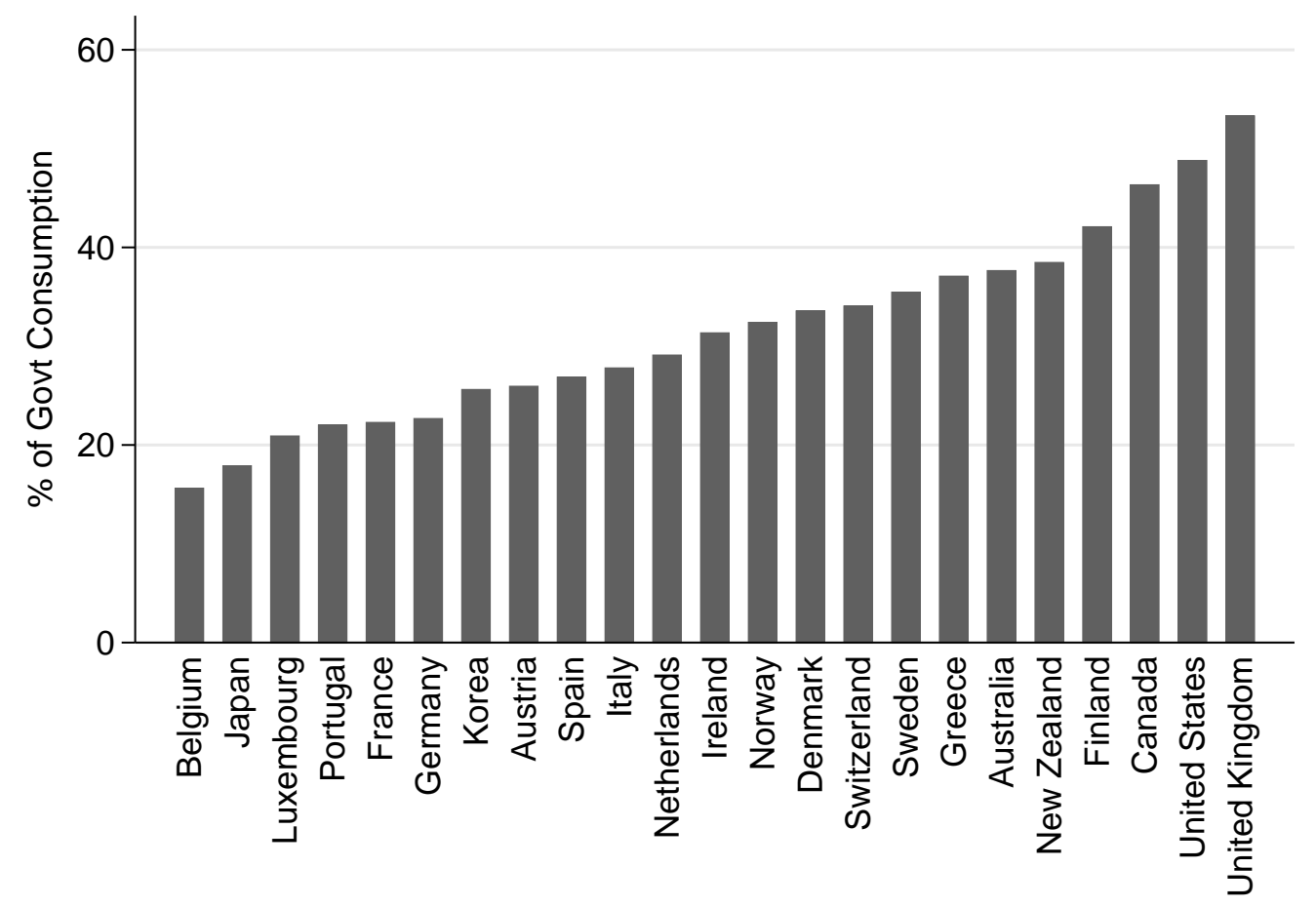

Figure 1: Domestic Government Outsourcing Across Individual Donors. Expenditures on government outsourcing to non-state actors for goods and services used by the government as percentage of government spending (excluding transfers) across donor countries in 2009. Source: OECD National Accounts Database (2011), and authors' calculation. 


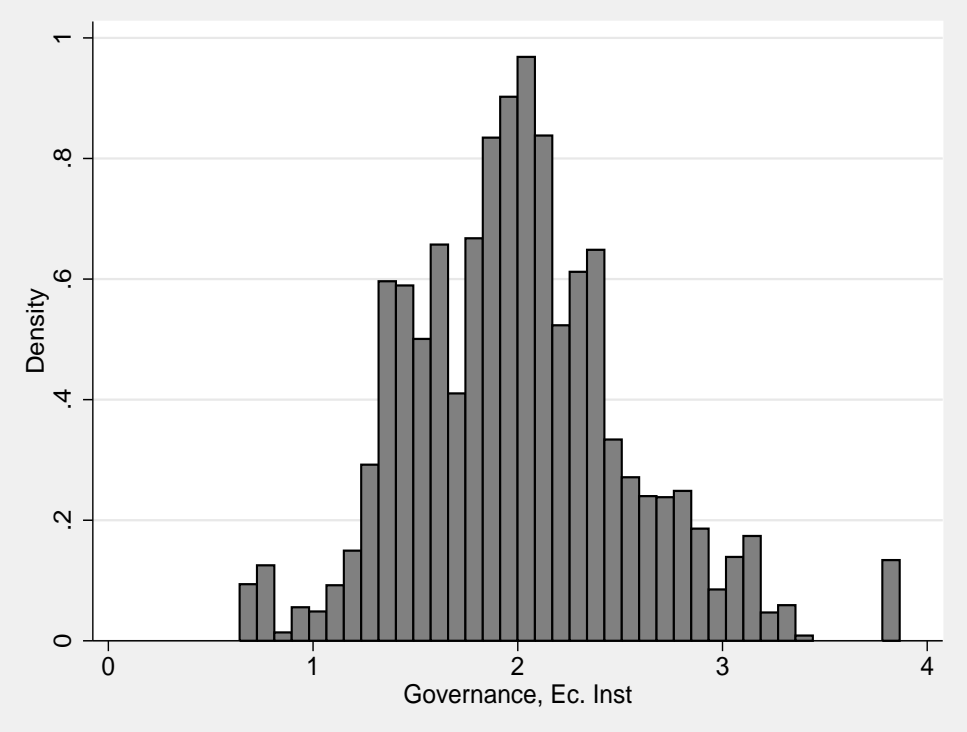

Figure 2: Histogram, Quality of Recipient Governance 


\begin{tabular}{lcccrr}
\hline \hline Variable & Observations & Mean & St. Deviation & Minimum & Maximum \\
\hline Bypass (log-transf) & 8760 & .80 & 7.56 & -20.00 & 18.66 \\
Lagged Bypass (log-transf) & 8760 & 0.50 & 7.69 & -20.00 & 13.33 \\
Governance & 8760 & 1.92 & 0.62 & .04 & 3.87 \\
LME & 8760 & 0.41 & 0.49 & 0 & 1 \\
LME*Recipient Governance & 8760 & 0.79 & 1.02 & 0 & 3.87 \\
CME & 8760 & 0.44 & 0.49 & 0 & 1 \\
CME*Recipient Governance & 8760 & 0.84 & 1.04 & 0 & 3.87 \\
Major Power & 8760 & .27 & .44 & 0 & 1 \\
Democracy & 8760 & -4.14 & 1.66 & -7 & -1 \\
Log(Disaster Deaths) & 8760 & 2.06 & 3.38 & -2.31 & 12.34 \\
Civil Conflict & 8760 & .17 & .38 & 0 & 1 \\
Log(Distance) & 8760 & 8.30 & .58 & 5.72 & 9.41 \\
Former Colony & 8760 & .66 & .47 & 0 & 1 \\
Log(Trade Intensity) & 8760 & 3.90 & 3.51 & -27.63 & 13.07 \\
Security Council & 8760 & .05 & .27 & 0 & 1 \\
Log(Total Aid) & 8760 & -15.49 & 2.75 & -26.31 & -6.65 \\
Log(Democracy Aid) & 8760 & -9.46 & 12.91 & -27.63 & 7.87 \\
Log(Social Sector Aid) & 8760 & -6.64 & 11.74 & -27.63 & 7.09 \\
\hline
\end{tabular}

Table 1: Descriptive Statistic of Estimation Sample; Table 1 Model 4 


\begin{tabular}{lccc}
\hline \hline & Model 1 & Model 2 & Model 3 \\
& Table 1, M4 & Table 1, M6 & Table 1, M8 \\
\hline LMEs*Rec Gov & $-0.53^{*}$ & & \\
& $(0.25)$ & & \\
CMEs*Rec Gov & 0.30 & & \\
& $(0.25)$ & & \\
Neoliberal*Rec Gov & & -0.40 & \\
& & $0.29)$ & \\
Scandinavian*Rec Gov & & $-0.70^{*}$ & \\
& & $0.32)$ & \\
Statist*Rec Gov & & 0.28 & \\
& & $0.29)$ & $-0.10^{* *}$ \\
Neocorporatist*Rec Gov & & 0.32 & 0.03 \\
& & & \\
Govt Outsourcing/GDP*Rec Gov & & & \\
& & & \\
N & & & \\
\end{tabular}

Table 2: Donor Political Economy and Bypassing Governments in Aid-Receiving Countries, 2005-2011; Three-Way-Fixed Effects (donor, recipient, year). $+p<0.10, * p<$ $0.05, * * p<0.01$. Only interaction coefficients reported. Model 1 adds donor fixed effects to Table 1 Model 4, which estimates results based on binary political economy division. Model 2 adds donor fixed effects to Table 1 Model 6, which estimates results based on four-fold political economy division. Model 3 adds donor fixed effects to Table 1 Model 8, which estimates results based on the domestic outsourcing measure. 
Binary Typology

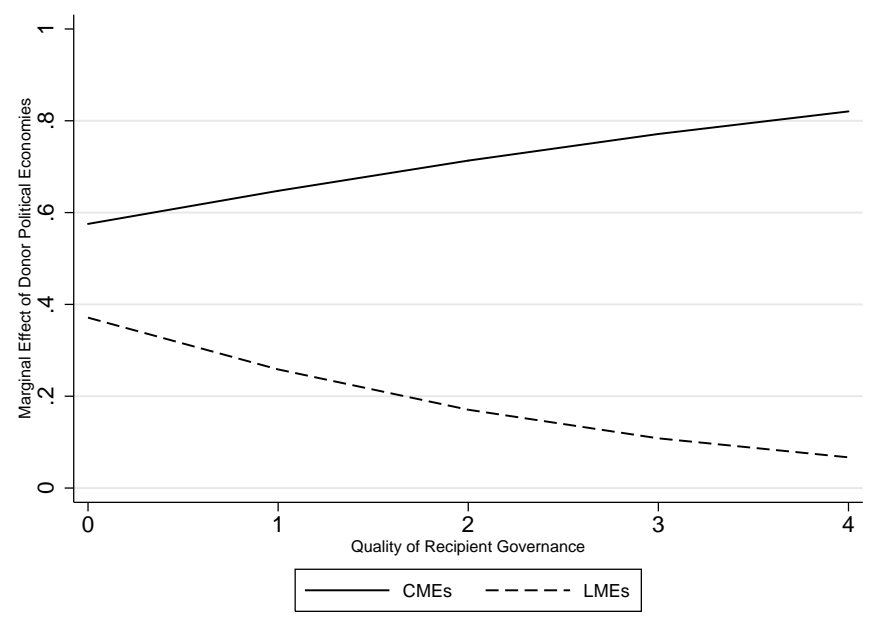

Four-Fold Typology

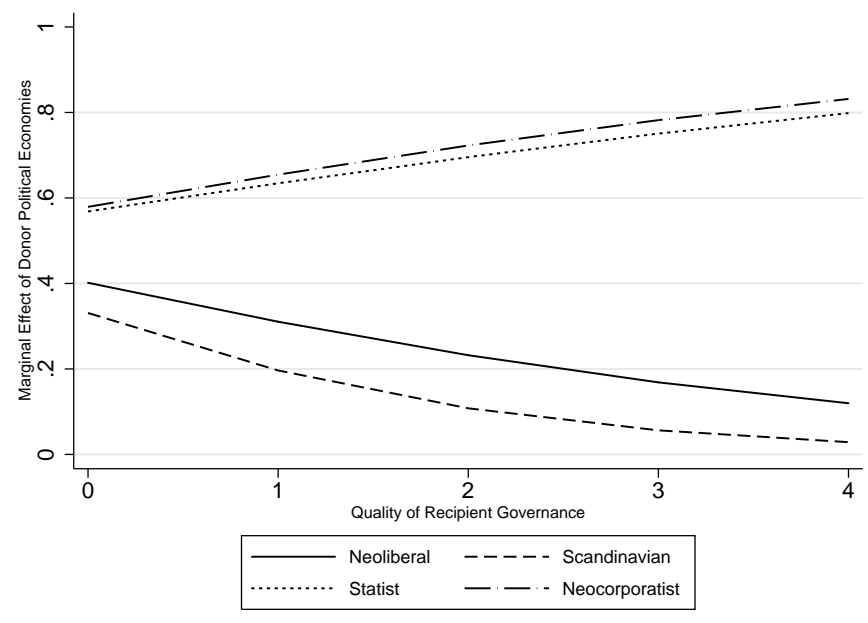

Figure 3: Plots of Interaction Coefficients of Three-Way Fixed Effects Political Economy Type Models, Appendix Table 2, Models 1 and 2. Left panel: plot based on Appendix Table 2, Model 1 (binary political economy division); Right panel: plot based on Appendix Table 1, Model 2 (four-fold political economy typology) Sources: OECD CRS Database (2013), and authors' calculation. 


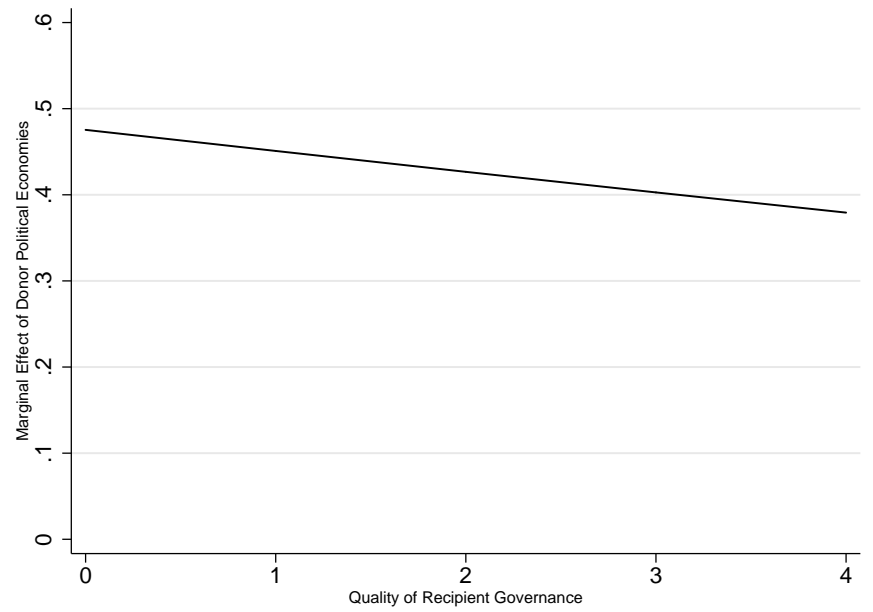

Figure 4: Plots of Interaction Coefficients of Three-Way Fixed Effects Government Outsourcing Model, Appendix Table 2, Model 3. Plot based on Appendix Table 2, Model 3. Sources: OECD CRS Database (2013), and authors' calculation. 


\begin{tabular}{lcc}
\hline \hline & Model 1 & Model 2 \\
\hline Lagged Bypass & & $0.529^{* *}$ \\
& & $(0.01)$ \\
Recipient Governance & 0.772 & 0.005 \\
& $(0.94)$ & $(0.93)$ \\
Govt Outsourcing/Govt Expenditure & $0.081^{* *}$ & $0.041^{* *}$ \\
Govt Outsourcing/Govt Expenditure*Gov & $(0.03)$ & $(0.01)$ \\
& -0.020 & -0.007 \\
Democracy & $(0.01)$ & $(0.01)$ \\
& -0.240 & -0.193 \\
Natural Disaster Deaths & $(0.29)$ & $(0.29)$ \\
Civil Conflict & -0.008 & -0.020 \\
Distance & $(0.03)$ & $(0.03)$ \\
& 0.175 & -0.062 \\
Former Colony & $(0.29)$ & $(0.28)$ \\
& $-0.879^{* *}$ & $-0.701^{* *}$ \\
Trade Intensity & $(0.23)$ & $(0.16)$ \\
& $2.789^{* *}$ & $1.366^{* *}$ \\
Security Council & $(0.71)$ & $(0.68)$ \\
& $-0.264^{* *}$ & $-0.130^{* *}$ \\
Major Power & $(0.06)$ & $(0.04)$ \\
Total Aid per capita & -0.197 & -0.136 \\
Democracy Aid & $(0.29)$ & $(0.21)$ \\
Social Sector Aid & $-2.552^{* *}$ & $-0.837^{* *}$ \\
N squared & $(0.22)$ & $(0.17)$ \\
& $-0.098^{* *}$ & -0.013 \\
& $(0.02)$ & $(0.05)$ \\
& $0.042^{* *}$ & 0.006 \\
& $(0.01)$ & $(0.01)$ \\
& $-0.047^{* *}$ & $-0.019^{* *}$ \\
& $(0.01)$ & $(0.01)$ \\
& 0.189 & 0.432 \\
& 10605 & 8760 \\
\hline
\end{tabular}

Table 3: Donor Government Outsourcing as \% of Gov't Spending and Bypassing Governments in Aid-Receiving Countries, 2005-2011. $+p<0.10, * p<0.05, * * p<0.01$. Constant (all columns) not reported; two-way year and recipient country fixed effects (Models 1 and 2); lagged bypass (Model 2). 


\begin{tabular}{|c|c|c|c|c|}
\hline & Model 1 & Model 2 & Model 3 & Model 4 \\
\hline Lagged Bypass & & $\begin{array}{c}0.475^{* *} \\
(0.02)\end{array}$ & & $\begin{array}{c}0.508^{* *} \\
(0.02)\end{array}$ \\
\hline Recipient Governance & $\begin{array}{l}1.228 \\
(1.03)\end{array}$ & $\begin{array}{l}0.125 \\
(1.13)\end{array}$ & $\begin{array}{l}0.284 \\
(0.91)\end{array}$ & $\begin{array}{l}-0.203 \\
(0.93)\end{array}$ \\
\hline LMEs*Rec Gov & $\begin{array}{l}-0.653 \\
(0.42)\end{array}$ & $\begin{array}{l}-0.377 \\
(0.35)\end{array}$ & $\begin{array}{c}-0.641^{*} \\
(0.38)\end{array}$ & $\begin{array}{l}-0.388 \\
(0.29)\end{array}$ \\
\hline LMEs & $\begin{array}{c}6.234^{* *} \\
(0.92)\end{array}$ & $\begin{array}{c}3.852^{* *} \\
(0.76)\end{array}$ & $\begin{array}{c}5.606^{* *} \\
(0.84)\end{array}$ & $\begin{array}{c}3.346^{* *} \\
(0.62)\end{array}$ \\
\hline CMEs*Rec Gov & $\begin{array}{l}0.457 \\
(0.48)\end{array}$ & $\begin{array}{l}0.383 \\
(0.37)\end{array}$ & $\begin{array}{l}0.408 \\
(0.45)\end{array}$ & $\begin{array}{l}0.243 \\
(0.30)\end{array}$ \\
\hline CMEs & $\begin{array}{c}2.206^{* *} \\
(0.96)\end{array}$ & $\begin{array}{l}1.262 \\
(0.76)\end{array}$ & $\begin{array}{l}1.682^{*} \\
(0.92)\end{array}$ & $\begin{array}{l}1.023 \\
(0.63)\end{array}$ \\
\hline Democracy & $\begin{array}{l}-0.308 \\
(0.29)\end{array}$ & $\begin{array}{l}-0.392 \\
(0.33)\end{array}$ & $\begin{array}{l}-0.155 \\
(0.28)\end{array}$ & $\begin{array}{l}-0.150 \\
(0.28)\end{array}$ \\
\hline Natural Disaster Deaths & $\begin{array}{l}0.003 \\
(0.04)\end{array}$ & $\begin{array}{l}-0.016 \\
(0.04)\end{array}$ & $\begin{array}{l}-0.001 \\
(0.03)\end{array}$ & $\begin{array}{c}-0.014 \\
(0.03)\end{array}$ \\
\hline Civil Conflict & $\begin{array}{l}0.161 \\
(0.28)\end{array}$ & $\begin{array}{l}0.023 \\
(0.36)\end{array}$ & $\begin{array}{l}0.203 \\
(0.28)\end{array}$ & $\begin{array}{l}-0.038 \\
(0.28)\end{array}$ \\
\hline Distance & $\begin{array}{c}-1.398^{* *} \\
(0.28)\end{array}$ & $\begin{array}{c}-1.250^{* *} \\
(0.20)\end{array}$ & $\begin{array}{c}-1.643^{* *} \\
(0.25)\end{array}$ & $\begin{array}{c}-1.185^{* *} \\
(0.17)\end{array}$ \\
\hline Former Colony & $\begin{array}{l}1.305 \\
(1.47)\end{array}$ & $\begin{array}{l}0.827 \\
(1.57)\end{array}$ & $\begin{array}{c}2.236^{* *} \\
(0.75)\end{array}$ & $\begin{array}{l}1.172 \\
(0.72)\end{array}$ \\
\hline Trade Intensity & $\begin{array}{c}-0.244^{* *} \\
(0.07)\end{array}$ & $\begin{array}{c}-0.147^{* *} \\
(0.05)\end{array}$ & $\begin{array}{c}-0.283^{* *} \\
(0.07)\end{array}$ & $\begin{array}{c}-0.139^{* *} \\
(0.04)\end{array}$ \\
\hline Security Council & $\begin{array}{l}-0.304 \\
(0.30)\end{array}$ & $\begin{array}{l}-0.314 \\
(0.25)\end{array}$ & $\begin{array}{l}-0.122 \\
(0.30)\end{array}$ & $\begin{array}{c}-0.134 \\
(0.22)\end{array}$ \\
\hline Number of NGOs & $\begin{array}{l}1.776 \\
(5.68)\end{array}$ & $\begin{array}{l}4.200 \\
(5.46)\end{array}$ & & \\
\hline Number of IGOs & $\begin{array}{l}-0.586 \\
(1.04)\end{array}$ & $\begin{array}{l}-0.677 \\
(1.00)\end{array}$ & & \\
\hline Number of NGOs and IGOs & & & $\begin{array}{c}3.600^{* *} \\
(0.46)\end{array}$ & $\begin{array}{c}2.310^{* *} \\
(0.44)\end{array}$ \\
\hline Major Power & $\begin{array}{c}-2.788^{* *} \\
(0.22)\end{array}$ & $\begin{array}{c}-0.794^{* *} \\
(0.19)\end{array}$ & $\begin{array}{c}-2.593^{* *} \\
(0.22)\end{array}$ & $\begin{array}{c}-0.795^{* *} \\
(0.16)\end{array}$ \\
\hline Total Aid per capita & $\begin{array}{c}-0.140^{* *} \\
(0.02)\end{array}$ & $\begin{array}{c}-0.106^{* *} \\
(0.05)\end{array}$ & $\begin{array}{c}-0.119^{* *} \\
(0.02)\end{array}$ & $\begin{array}{c}-0.085^{*} \\
(0.05)\end{array}$ \\
\hline Democracy Aid & $\begin{array}{c}0.022^{*} \\
(0.01)\end{array}$ & $\begin{array}{l}-0.001 \\
(0.01)\end{array}$ & $\begin{array}{l}0.014 \\
(0.01)\end{array}$ & $\begin{array}{l}-0.005 \\
(0.01)\end{array}$ \\
\hline Social Sector Aid & $\begin{array}{l}-0.017 \\
(0.01)\end{array}$ & $\begin{array}{l}-0.000 \\
(0.01)\end{array}$ & $\begin{array}{c}-0.026^{* *} \\
(0.01)\end{array}$ & $\begin{array}{l}-0.008 \\
(0.01)\end{array}$ \\
\hline $\mathrm{R}$ squared & 0.223 & 0.420 & 0.221 & 0.441 \\
\hline $\mathrm{N}$ & 8257 & 6582 & 10346 & 8544 \\
\hline
\end{tabular}

Table 4: Donor Political Economy and Bypassing Governments in Aid-Receiving Countries, 2005-2011. $+p<0.10, * p<0.05, * * 9<0.01$. Constant (all columns) not reported; two-way year and recipient fixed effects (Models 1 to 4); lagged bypass variable (Models 2 and 4). 


\begin{tabular}{|c|c|c|c|c|}
\hline & Model 1 & Model 2 & Model 3 & Model 4 \\
\hline Lagged Bypass & & & $\begin{array}{c}0.506^{* *} \\
(0.01)\end{array}$ & $\begin{array}{c}0.536^{* *} \\
(0.01)\end{array}$ \\
\hline Initial Recipient Governance & $\begin{array}{c}5.183^{* *} \\
(0.67)\end{array}$ & $\begin{array}{l}-0.049 \\
(0.34)\end{array}$ & $\begin{array}{c}3.398^{* *} \\
(0.63)\end{array}$ & $\begin{array}{l}-0.182 \\
(0.20)\end{array}$ \\
\hline Recipient Governance & $\begin{array}{l}0.337 \\
(0.91)\end{array}$ & $\begin{array}{c}-1.316^{* *} \\
(0.49)\end{array}$ & $\begin{array}{l}-0.119 \\
(0.94)\end{array}$ & $\begin{array}{c}-0.661^{* *} \\
(0.33)\end{array}$ \\
\hline CMEs*Rec Gov & $\begin{array}{l}0.400 \\
(0.44)\end{array}$ & $\begin{array}{l}0.256 \\
(0.42)\end{array}$ & $\begin{array}{l}0.263 \\
(0.29)\end{array}$ & $\begin{array}{l}0.206 \\
(0.27)\end{array}$ \\
\hline CMEs & $\begin{array}{l}1.716^{*} \\
(0.89)\end{array}$ & $\begin{array}{c}1.881^{* *} \\
(0.87)\end{array}$ & $\begin{array}{l}1.004 \\
(0.61)\end{array}$ & $\begin{array}{l}0.928 \\
(0.56)\end{array}$ \\
\hline LMEs*Rec Gov & $\begin{array}{c}-0.751^{*} \\
(0.38)\end{array}$ & $\begin{array}{c}-0.879^{* *} \\
(0.37)\end{array}$ & $\begin{array}{l}-0.419 \\
(0.28)\end{array}$ & $\begin{array}{l}-0.406 \\
(0.25)\end{array}$ \\
\hline LMEs & $\begin{array}{c}5.884^{* *} \\
(0.85)\end{array}$ & $\begin{array}{c}5.924^{* *} \\
(0.83)\end{array}$ & $\begin{array}{c}3.448^{* *} \\
(0.60)\end{array}$ & $\begin{array}{c}3.114^{* *} \\
(0.54)\end{array}$ \\
\hline Democracy & $\begin{array}{r}-0.256 \\
(0.29)\end{array}$ & $\begin{array}{l}-0.157 \\
(0.11)\end{array}$ & $\begin{array}{l}-0.215 \\
(0.29)\end{array}$ & $\begin{array}{c}-0.084 \\
(0.06)\end{array}$ \\
\hline Natural Disaster Deaths & $\begin{array}{l}-0.009 \\
(0.03)\end{array}$ & $\begin{array}{c}0.152^{* *} \\
(0.04)\end{array}$ & $\begin{array}{l}-0.023 \\
(0.03)\end{array}$ & $\begin{array}{c}0.068^{* *} \\
(0.02)\end{array}$ \\
\hline Civil Conflict & $\begin{array}{l}0.208 \\
(0.27)\end{array}$ & $\begin{array}{c}0.694^{* *} \\
(0.29)\end{array}$ & $\begin{array}{l}-0.034 \\
(0.28)\end{array}$ & $\begin{array}{l}0.321^{*} \\
(0.19)\end{array}$ \\
\hline Distance & $\begin{array}{c}-1.653^{* *} \\
(0.25)\end{array}$ & $\begin{array}{c}-0.727^{* *} \\
(0.22)\end{array}$ & $\begin{array}{c}-1.206^{* *} \\
(0.17)\end{array}$ & $\begin{array}{c}-0.474^{* *} \\
(0.12)\end{array}$ \\
\hline Former Colony & $\begin{array}{l}-1.014 \\
(1.15)\end{array}$ & $\begin{array}{c}0.833^{* *} \\
(0.31)\end{array}$ & $\begin{array}{l}-1.016 \\
(1.08)\end{array}$ & $\begin{array}{c}0.486^{* *} \\
(0.17)\end{array}$ \\
\hline Trade Intensity & $\begin{array}{c}-0.289^{* *} \\
(0.07)\end{array}$ & $\begin{array}{c}-0.297^{* *} \\
(0.05)\end{array}$ & $\begin{array}{c}-0.143^{* *} \\
(0.04)\end{array}$ & $\begin{array}{c}-0.134^{* *} \\
(0.03)\end{array}$ \\
\hline Security Council & $\begin{array}{l}-0.193 \\
(0.29)\end{array}$ & $\begin{array}{l}0.148 \\
(0.31)\end{array}$ & $\begin{array}{l}-0.153 \\
(0.21)\end{array}$ & $\begin{array}{l}0.053 \\
(0.20)\end{array}$ \\
\hline Major Power & $\begin{array}{c}-2.573^{* *} \\
(0.21)\end{array}$ & $\begin{array}{c}-3.057^{* *} \\
(0.19)\end{array}$ & $\begin{array}{c}-0.820^{* *} \\
(0.16)\end{array}$ & $\begin{array}{c}-0.991^{* *} \\
(0.14)\end{array}$ \\
\hline Total Aid per capita & $\begin{array}{c}-0.114^{* *} \\
(0.02)\end{array}$ & $\begin{array}{c}-0.116^{* *} \\
(0.02)\end{array}$ & $\begin{array}{c}-0.076^{*} \\
(0.04)\end{array}$ & $\begin{array}{c}-0.086^{* *} \\
(0.04)\end{array}$ \\
\hline Democracy Aid & $\begin{array}{l}0.012 \\
(0.01)\end{array}$ & $\begin{array}{c}0.025^{* *} \\
(0.01)\end{array}$ & $\begin{array}{l}-0.007 \\
(0.01)\end{array}$ & $\begin{array}{l}0.000 \\
(0.01)\end{array}$ \\
\hline Social Sector Aid & $\begin{array}{c}-0.029^{* *} \\
(0.01)\end{array}$ & $\begin{array}{c}-0.024^{* *} \\
(0.01)\end{array}$ & $\begin{array}{l}-0.010 \\
(0.01)\end{array}$ & $\begin{array}{l}-0.006 \\
(0.01)\end{array}$ \\
\hline $\mathrm{R}$ squared & 0.221 & 0.172 & 0.441 & 0.425 \\
\hline $\mathrm{N}$ & 10605 & 10605 & 8760 & 8760 \\
\hline
\end{tabular}

Table 5: Donor Political Economy and Bypassing Governments in Aid-Receiving Countries, 2005-2011. $+p<0.10, * p<0.05, * * p<0.01$. Constant (all columns) not reported; year fixed effects (no recipient fixed effects) in Models 2 and 4; two-way year and recipient fixed effects in Models 1 and 3; lagged bypass variable in Models 3 and 4. 
Marginal Effects of Donor Political Economy on Bypass Across Quality of Recipient Governance

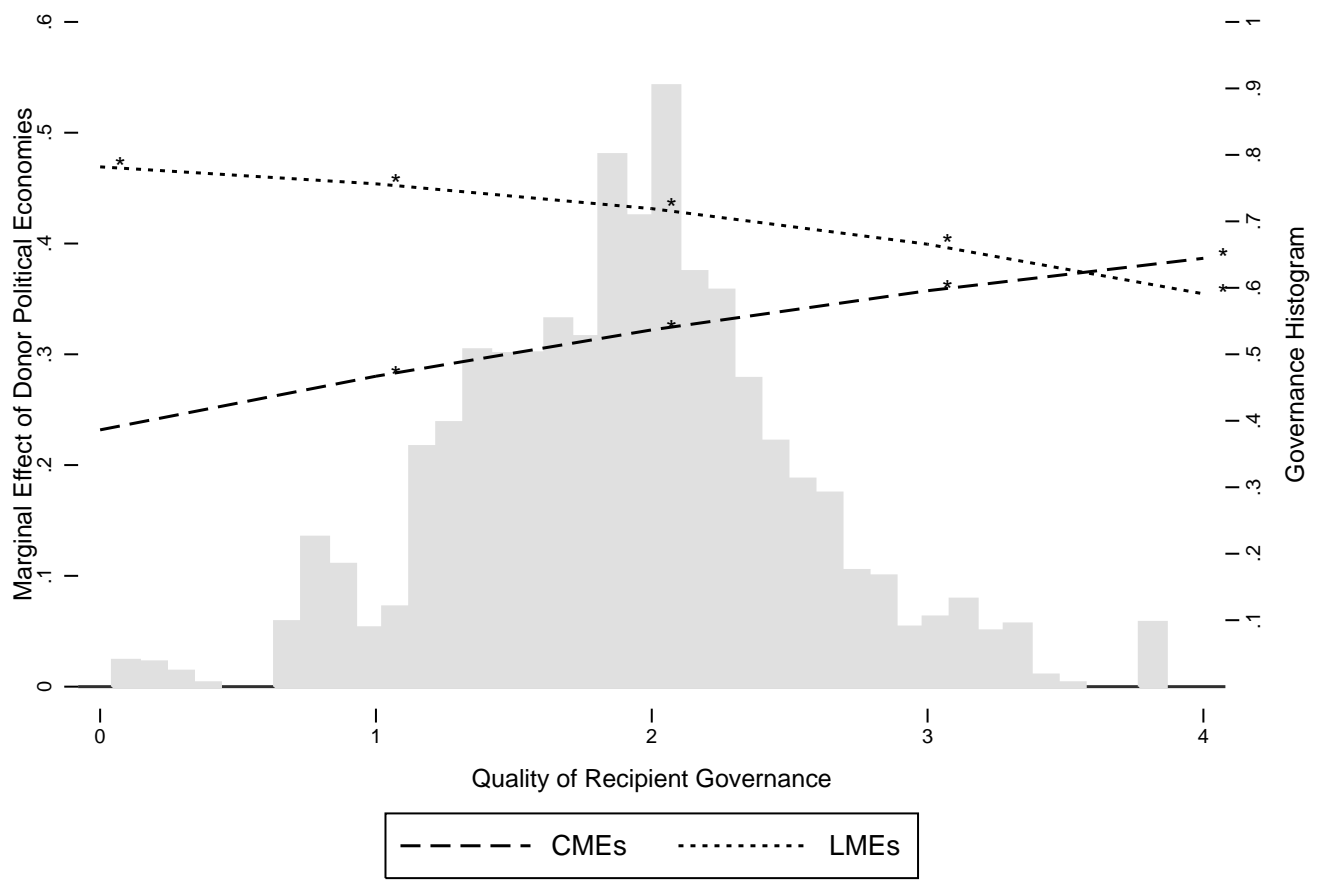

Figure 5: Marginal Effects of Political Economy Types Across Quality of Recipient Governance, Controlling for Initial Governance Conditions in Recipient Country. Effects of binary political economy division estimated in Appendix Table A4, Model 3. Stars signal statistical significance at 0.05 level. Sources: OECD CRS Database (2013), and authors' calculation. 


\begin{tabular}{c|l|l}
\hline \hline Number of Respondents & Agency & Country \\
\hline 4 & State Department & United States \\
4 & USAID & United States \\
2 & Millennium Challenge Corporation & United States \\
1 & Treasury & United States \\
1 & Office of Budget and Management & United States \\
6 & Ministry of Foreign Affairs & Sweden \\
7 & Swedish International Development Cooperation Agency & Sweden \\
4 & Ministry of Foreign Affairs & France \\
3 & French Agency for Development & France \\
9 & Ministry of Finance & France \\
4 & Ministry of Development Cooperation & Germany \\
3 & Kreditanstalt fuer Wiederaufbau (KfW) & Germany \\
2 & Ministry for Foreign Affairs & Japan \\
\hline
\end{tabular}

Table 6: Survey respondents by agency and country. 